School of Finance

University of St.Gallen

INDIVIDUAL INVESTOR ACTIVITY AND PERFORMANCE

Magnus DaHLQUiST

Jose VinCENTE MARTINEZ

PAUL SÖDERLIND

WORKING PAPERS ON FinANCE NO. 2014/8

SWISS INSTITUTE OF BANKING AND FINANCE (S/BF - HSG)

THIS VERSION: SEPTEMBER 2016 


\title{
Individual Investor Activity and Performance
}

\author{
Magnus Dahlquist José Vicente Martinez Paul Söderlind* \\ September 8, 2016
}

\begin{abstract}
We examine the daily activity and performance of a large panel of individual investors in Sweden's Premium Pension System. We find that active investors earn higher returns and risk-adjusted returns than inactive investors. A performance decomposition analysis reveals that most of the outperformance of active investors is the result of these investors successfully timing mutual funds and asset classes. While activity is beneficial for some investors, extreme flows out of mutual funds affect funds' net asset values negatively for all investors. Financial advisors, by contributing to coordinate investments and redemptions, exacerbate these negative effects.
\end{abstract}

Keywords: 401(k), coordinated fund changes, defined contribution, financial advisors, mutual fund flows.

JEL Classification Numbers: G11, G23, H55.

\footnotetext{
${ }^{*}$ We are grateful to Finansinspektionen, Fondbolagens Förening, the Swedish Pensions Agency, and Svensk Fondstatistik for providing us with data, and to NASDAQ OMX for financial support. Special thanks to Marcela Cohen Birman and Bengt Norrby at the Swedish Pensions Agency for helping us with the data. We have benefited from the comments of Daniel Barr, Daniel Dorn, Woodrow Johnson, Howard Jones, Andrew Karolyi, Steffen Meyer, Ľuboš Pástor, Jonathan Reuter, Annika Sundén, two anonymous referees; seminar participants at Copenhagen Business School, Goethe University Frankfurt, Lund University, London Business School, University of Gothenburg, University of Porto, ISCTE-IUL; and participants in the European Finance Association Meeting in Copenhagen, the Luxembourg Asset Management Summit, the NBER Household Finance Meeting at the University of Oxford, and the NETSPAR conference at Tilburg University. Dahlquist is at the Stockholm School of Economics and is a research fellow at the Center for Economic Policy Research (CEPR); e-mail: magnus.dahlquist@hhs.se. Martinez is at the University of Connecticut; e-mail: jose.martinez@business.uconn.edu. Söderlind is at the University of St. Gallen and the Swiss Institute of Banking and Finance, and is a research fellow at the Center for Economic Policy Research (CEPR); e-mail: Paul.Soderlind@unisg.ch .
} 


\section{Introduction}

Defined contribution plans are increasingly becoming the main source of retirement income $1^{1}$ These plans have many attractive features, such as portability and flexibility, but they place significant responsibility on individuals to make decisions and monitor their choices. To the concern of pension authorities, a wealth of evidence indicates that most plan participants are not actively engaged in this process, hardly ever adjusting their allocations to address changing market conditions or personal circumstances (see, e.g., Madrian and Shea, 2001; Benartzi and Thaler, 2001, 2007; Choi, Laibson, Madrian, and Metrick, 2002; Agnew, Balduzzi, and Sundén, 2003; and Chetty, Friedman, Leth-Petersen, Nielsen, and Olsen, 2014).

In this study we investigate the relationship between individual investor activity and portfolio performance in a modern defined contribution plan. We use a detailed sample of six million pension savers in the Swedish Premium Pension System. The data allow us to track the portfolios of individuals which are invested in mutual funds, and the daily changes they make to these portfolios, over a period of ten years. We also investigate whether the activity of some pension investors affects other investors in the system.

We find that investors who actively manage their pension accounts earn significantly higher returns than inactive investors. Investors who have been inactive over the previous year (a category that includes $93.5 \%$ of the individuals in our sample) earn average returns of $3.82 \%$ per year, whereas investors in activity deciles 1 to 9 (5.8\% of the individuals) earn average returns of $6.86 \%$ per year. The investors in the highest activity decile $(0.6 \%$ of the individuals) earn average returns of $12.57 \%$ per year. Risk-adjusting the returns produces similar results, suggesting that the higher returns of active investors are attributable to better investment performance rather than to risk compensation. The better investment performance we document for these relatively small categories of investors is in contrast to

\footnotetext{
${ }^{1}$ Pensions and Investments reported on May 13, 2013, that assets under management in defined contribution plans worldwide are projected to reach USD 13.7 trillion by the end of 2016 .
} 
that of the average investor in the pension system, who does not outperform.

A performance decomposition analysis reveals that the better performance of active investors is primarily the result of these investors successfully timing funds and asset classes. While these two timing components are close to zero for investors who were inactive over the previous year, their sum is as high as $6.65 \%$ per year for highly active investors. Highly active investors also seem better at selecting funds within an asset class. The difference in the average fund selection component between highly active and inactive investors is $1.39 \%$ per year. On the other hand, the average asset class returns for inactive and active investors are similar.

The importance of fund changes in explaining the observed differences in performance between active and inactive investors is highlighted by the fact that these differences would have been much smaller had active investors not made any changes to their portfolios and stayed with their original funds.

To further investigate how fund changes affect investors' performance, we compare the returns of the newly chosen funds with the returns of the discarded funds. We find that, following a portfolio change, the new funds outperform the old funds over all the horizons we study. For example, for highly active investors the average return on the new portfolio exceeds the average return on the old portfolio by an annualized $4.67 \%$ in the week following the portfolio change; and by an annualized $3.74 \%$ in the month following that change. The higher returns due to a portfolio change are usually obtained in the first month after the change. After a month, the outperformance of the new funds weakens but does not reverse. However, the outperformance is not just a matter of a few days and cannot be attributed to investors being able to trade at stale prices. Interestingly, when inactive investors change funds, they also switch to funds that do better than the discarded ones in the first few months after the change. The difference between highly active and inactive investors is that highly active investors make many more changes, and hold the funds they switch into 
for significantly shorter periods, which are the periods during which these funds typically outperform.

Part of highly active investors' timing success seems to be related to their tendency to invest in recent good past performers. Our evidence indicates that these investors chase past performance and in doing so they (consciously or unconsciously) take advantage of shortterm persistence in fund performance (see Bollen and Busse, 2004) in a context where the absence of transaction costs makes it economical to do so. Less active investors also choose recent good past performers when they change funds, but unlike highly active investors they hold onto these funds for too long. Only highly active investors have a portfolio that is consistently invested in recent good past performers. This behavior explains about $45 \%$ of highly active investors' outperformance of inactive investors.

Investors in the Premium Pension System can either manage their retirement portfolios on their own or hire a financial advisor to help them. Many of the fund changes we observe are simultaneous, which we attribute to financial advisors making recommendations and managing individual portfolios on a discretionary basis. ${ }^{2}$ We estimate that coordinated investors accounted for $10 \%$ of the population in 2010, but executed $80 \%$ of all fund changes. Coordinated investors do marginally better than inactive investors on a gross-of-fees basis, but their outperformance vanishes and even turns into underperformance once we deduct typical financial advisor fees. However, these differences are hardly ever statistically significant.

Our results also reveal a dark side to high investor activity. Active investors force mutual fund managers to trade more, which can negatively impact fund returns. Since trading costs are borne by the fund, shareholders who trade implicitly impose a financial burden on others

\footnotetext{
${ }^{2}$ Financial advisors are known to direct clients into similar portfolios (Foerster, Linnainmaa, Melzer, and Previtero, 2015). The specialized advisors that advise investors in the Swedish pension system tend to execute identical fund changes for large numbers of clients at the same day, resulting in extreme levels of coordination in individual portfolios and flows. These coordinated changes are implemented using what the pension agency refers to as web robots (see www.inspsf.se).
} 
in the fund. This problem is likely aggravated by the presence of financial advisors who magnify trading demands and the coordination of these demands. The sources of these costs vary: brokerage and price impact costs from increased fund trading (Edelen, 1999), fire sales of assets following sudden fund redemptions (Coval and Stafford, 2007), administrative costs, and exclusion of illiquid investment options from pension menus $3^{3}$ These costs can be large when there are no load, exit, or redemption fees to dampen investor trading. Our results suggest that the costs created by active investors can be as high as $0.10 \%$ of a fund's assets under management for a single extreme fund outflow, with financial advisors being behind more than $90 \%$ of these extreme flows.

We contribute to the literature on individual investor behavior by investigating the relationship between investor activity and portfolio performance in a modern defined contribution plan. Previous work on the relationship between activity and performance, including the influential work of Barber and Odean (2000, 2002), has focused on individuals' stock trading activity in brokerage accounts. The evidence on managed funds has so far been limited and only indirect. In the mutual fund literature evidence in favor of "smart money" effects (see, e.g., Gruber, 1996; Zheng, 1999; and Keswani and Stolin, 2008) coexists with studies pointing to the absence of such effect (Sapp and Tiwari, 2004) and even "dumb money" effects (Frazzini and Lamont, 2008), depending on the horizons and frequencies studied. Studies of pension investors that rely on aggregate data have failed to find any correlation between daily changes in equity allocations and future equity returns (Choi, Laibson, and Metrick, 2002; and Agnew, Balduzzi, and Sundén, 2003). Our detailed data allow us to track the activity and performance of individual investors over several years and relate them to each other. The picture emerging from our analysis is that pension investors who are active do better than inactive ones, in a context where it is costless to make fund changes.

\footnotetext{
${ }^{3}$ Studies analyzing the costs of flows and fire sales include Chordia (1996), Greene and Hodges (2002), Alexander, Cici, and Gibson (2007), and Chen, Goldstein, and Jiang (2010).
} 
Working with individual portfolios tracked at a daily frequency, rather than aggregate flows, also allows us to make two distinct contributions to the smart money literature. First, a more precise measurement of smart money effects. Using daily data we can measure the performance of new and old funds from the moment the portfolio change takes place. Given that the performance difference between new and old funds is usually the largest immediately after the change, the effects we report are generally larger than those previously documented in the literature. The fact that we concentrate on active fund changes (that result in active flows), while most smart money studies rely on actual or estimated flows typically including many flows that are automatic or the result of old decisions (e.g., periodic payments into pension or 401(k) accounts) also contributes to this result. Second, we provide evidence about the heterogeneity in investor smartness. While most investors look smart when we consider the performance of their funds shortly after the portfolio change, only a fraction of them are truly smart when we consider their holding periods.

We also contribute to the literature on the impact of asset flows on mutual fund performance. Our results not only suggest that inactive investors do worse than active ones, but also that the outperformance of active investors is to some extent achieved at the expense of inactive investors. This result highlights a dark side to investor activity and is broadly in line with the observations of Edelen (1999) and Johnson (2004) on mutual funds.

Finally, we also contribute to the emerging literature on the role of financial advisors (see, e.g., Inderst and Ottaviani, 2012; Mullainathan, Nöth, and Schoar, 2012; Bhattacharya, Hackethal, Kaesler, Loos, and Meyer, 2012; Hackethal, Haliassos, and Jappelli, 2012; Gennaioli, Shleifer, and Vishny, 2015; and Foerster, Linnainmaa, Melzer, and Previtero, 2015). We draw attention to a consequence of their activity that only now is starting to be appreciated: the coordination financial advisors induce in individuals' trading demands (see also Cuevas and Bernhardt, 2016; and Da, Larrain, Sialm, and Tessada, 2016). 


\section{The Premium Pension System in Sweden}

The public pension system in Sweden consists of two components: a notional defined contribution plan financed on a pay-as-you-go basis and a fully funded individual account system known as the Premium Pension System (PPS). The contribution rate to the overall system is $18.5 \%$ of the gross income of an individual; $16 \%$ is paid to the notional defined contribution segment, while $2.5 \%$ is credited to the funded individual accounts of the PPS. Contributions to the system are capped at an income level that is adjusted every year. In 2010, the cap was set to SEK 383,250 or approximately USD 55,000. In addition, a means-tested benefit provides a minimum pension $4^{4}$

The focus of this paper is the activity and performance of individual investors in the PPS (the fully funded participant-directed accounts), not the pension system as a whole. The PPS system functions like a national 401(k) plan. Participation is mandatory and the coverage is universal. By 2010 the system included more than six million individuals and

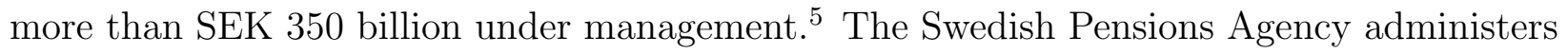
the system and acts as a clearing house, but it is entirely up to individual participants to select how to invest their personal funds.

The investment options offered to individual participants in the PPS are a subsample of the mutual funds offered to retail investors. In 2000, at the time of the first fund selections, 456 funds were registered in the system, a number that had grown to 778 funds by the end

\footnotetext{
${ }^{4}$ The pension rights in the notional defined contribution plan are notional in the sense of being linked to the Swedish income index, with a balancing mechanism designed to maintain the financial stability of the system. See Sundén (2006) for a discussion of the overall Swedish pension reforms of the 1990s. For studies of the PPS, see also Cronqvist and Thaler (2004) and Palme, Sundén, and Söderlind (2007).

${ }^{5}$ The individual accounts of the PPS may represent a small portion of some investors' total savings. However, the amounts involved are not insignificant, and they may be highly relevant for individuals who are less likely to participate in the stock market or invest in mutual funds on their own. For example, the data in Dahlquist, Setty, and Vestman (2016) reveal that a typical individual's savings in the premium pension system corresponds to $2 / 3$ of his or her financial savings outside of the pension system. Estimates from the Pensions Agency (Swedish Pensions Agency, 2014) suggest that as much as $30 \%$ of an individual's pension at retirement can be expected to come from the premium pension.
} 
of our sample period in May 2010. During the period we study, a total of 1,229 different funds have been offered in the system ${ }^{6}$ Most of these funds are equity funds (898 funds), a significant proportion of which invest primarily in international equities. The rest are fixed income funds (191 funds), investing mostly in Swedish bonds (more than $85 \%$ of their assets are invested this way), and balanced and target date funds (139 funds), investing in equity and fixed income securities. Table I presents a summary of the funds on offer in the system, including number of funds, average assets under management, average fees and expenses (total expense ratio plus fee charged by the Swedish Pensions Agency to investors minus a fee rebate demanded by the agency from the participating fund managers), and average annual fund returns in each of thirteen different investment categories. Individuals may choose up to five funds at any point in time and can change their allocations on a daily basis at no additional cost. The government established in 2000 a default fund for individuals who do not make an investment choice. The default fund, a relatively low-cost fund, has invested in stocks and bonds to achieve high long-term returns with low overall risk. The default fund became a life-cycle (target date) fund in May 2010.

Information about the funds in the PPS is presented on the pensions agency's website and in a catalogue distributed to participants on request. The funds are listed by type, for example, fixed income, balanced, target date, and equity funds, and for each fund there is information such as the historical rate of return and risk (measured over several horizons), the fee, and the fund major holdings.

Fund managers charge the same management fees to pension investors as they do to retail investors (see Palme, Sundén, and Söderlind, 2007). Because account administration is handled by the Swedish Pensions Agency, fund managers must rebate a share of their fees to the agency, which passes this rebate on to the individuals. As a result, the typical

\footnotetext{
${ }^{6}$ Any fund management company licensed to do business in Sweden is allowed to participate in the system. Unlike what happens in other defined contribution pension plans (see Sialm, Starks, and Zhang, 2015), the Swedish Pensions Agency does not actively manage the menu of funds on offer.
} 
effective fee in the pension system is lower than in the retail market. In 2010, the assetweighted average fund fee after the rebate was $0.37 \%$ of assets for active investors and $0.15 \%$ for those in the default fund. The Swedish Pensions Agency charges a fixed administration fee to all participants. In 2010, this fee amounted to $0.16 \%$ of the assets in the system. Hence, the average total fee paid by pension investors was $0.53 \%$ of assets for active investors and $0.31 \%$ for those in the default fund.

\section{Data}

We obtained data from the Swedish Pensions Agency on more than six million individual investors and all offered investment options (mutual funds) in the Premium Pension System (PPS). For each individual in the system we observe their initial fund choices and all their fund changes on a daily basis. We also have data on individuals' gender, age, and pension rights (a function of individuals' pensionable income that we use as an income proxy). Since tracking the portfolios and actions of more than six million individuals over more than two thousand trading days soon becomes computationally demanding, we randomly draw 100,000 individuals from this population. Out of these, we consider 70,755 individuals who were in the system when it was launched in September 2000 and stayed in it until the end of our sample period in May 2010.7 This sample selection procedure does not generate endogeneity problems as the only ways out of the sample are to retire at the statutory age, become disabled, or die.

The fund data cover all funds offered to pension investors during the sample period, including the funds that have been terminated or taken out of the system. Hence, our sample is free from survivorship and backfill biases. We consider returns net of fund management and pension administration fees and expenses, to reflect actual investor experience. Returns

\footnotetext{
${ }^{7}$ In Table II and the Online Appendix we provide analysis showing that the sample and the population are very similar in terms of investor composition, activity, returns, and standard deviation of those returns.
} 
are also adjusted to reflect the effect of the fee rebates that the Swedish Pensions Agency negotiates on behalf of pension investors. The information necessary to make these adjustments (i.e., fund management fees, administration fees, and fee rebates) was obtained from the agency. With these two pieces of information, individual fund holdings within the PPS and fund returns, we re-construct individuals' portfolios, day by day, and compute portfolio returns. The Swedish Pension Authority requires funds in the PPS to have no entry and exit fees (even if the funds have them in the retail market outside the pension system). This means that there are no direct trading costs for individuals in the PPS.

Early in the life of the PPS an industry of mass-market financial advisors, similar to robo-advisors, emerged. These financial advisors offer a non-individualized service characterized by little advisor-investor contact that induces a high degree of coordination among their customers' fund changes. Mass-market financial advisors typically use the same portfolio of funds for all, or large groups of, their customers, and modify or rebalance all these portfolios at the same time. We use this fact to classify accounts as directed by individuals (non-coordinated investors) or financial advisors (coordinated investors). We do that by applying a simple algorithm to the full population of more than six million individuals. We classify an individual as being coordinated if the following two conditions hold. First, the individual has at least once made exactly the same fund change (same funds of origin and destination, and same change date) as a thousand or more other individuals. Second, in at least a fifth of the fund changes made by that individual, he or she has made exactly the same change as at least ten other individuals 8 Using this approach we find 8,115 coordinated investors and 62,640 non-coordinated investors in our sample of 70,755 individuals. Alternative classification algorithms produce similar results, indicating that in most cases

\footnotetext{
${ }^{8}$ Conversations with officers at the Swedish Pensions Agency reveal that web-based coordinated changes are frequent and often executed from a single IP address. The changes often involve individuals from similar geographical or age groups. Reassuringly, our algorithm, developed following exchanges with the agency, delivers estimates of the number of individuals on an advisory relation that closely match those obtained by the agency in a survey of financial advisors.
} 
coordination is either extreme or very mild or non-existent.9

In this study we are particularly interested in individuals' account activity which we measure using the number of fund changes they make (excluding changes carried out by the PPS when a fund is discontinued or replaced by another). Table II presents the numbers and percentages of individuals in various investor activity ranges, both in our sample and the population. In this table there are two categories for individuals who have never made a fund change: the default fund category refers to individuals who have been in the default fund for the entire sample period; the no change category refers to individuals who have made an active fund choice when the system was launched, but who have not made a fund change since. The remaining categories are of individuals who have made a fund change at least once.

We find strong evidence of inertia in fund choices ${ }^{10}$ Approximately $69 \%$ of the noncoordinated individuals in our sample made no fund changes during the 2000-2010 period: $30.2 \%$ stayed in the default fund for the entire sample period, and $39.0 \%$ were initially active and chose one or several funds but have not made a fund change since. In the active investor categories, $16.0 \%$ made one fund change; $9.2 \%$ made between 2 and 5 changes; $4.1 \%$ between 6 and $20 ; 1.2 \%$ between 21 and 50; and $0.3 \%$ more than 50 changes. The small number of fund changes is consistent with previous evidence of low activity in pension accounts, but is somewhat surprising as these retirement accounts have no transaction costs (see Agnew, Balduzzi, and Sundén, 2003, and Choi, Laibson, and Metrick, 2002, for discussions).

In further analysis we find that the typical portfolio reallocation for the non-coordinated group of investors involves almost $50 \%$ of the old portfolio. In more than $40 \%$ of the fund changes, non-coordinated individuals reallocate their pension savings within the same asset

\footnotetext{
${ }^{9}$ Since it is unlikely that coordinated individuals employed a financial advisor during the entire sample period, later on we also estimate and report results for the coordinated period.

${ }^{10}$ Madrian and Shea (2001), Choi, Laibson, Madrian, and Metrick (2002), and Agnew, Balduzzi, and Sundén (2003) report similar results.
} 
class (equity, fixed income, or balanced funds) and in less than $10 \%$ of the changes these individuals invest in completely different asset classes. It also appears that men change funds more frequently than women do, as do high income individuals, while age is unrelated to the number of fund changes.

Coordinated investors are much more active than non-coordinated investors. For example, $31.4 \%$ of coordinated investors made more than 20 changes, whereas only $1.2 \%$ of non-coordinated investors were equally active. Coordinated investors represent only a small part of the total population (approximately 10\% of the population in 2010), but account for a disproportionately large share of the fund changes in the system (approximately $80 \%$ of all changes in 2010).

\section{Methodology and Results}

Individuals who would like to actively manage their portfolios can do that on their own or they can hire a financial advisor to do that for them. These two forms of activity, direct and by proxy, will result in fund changes being made to portfolios, but their implications are clearly different. For this reason we analyze non-coordinated (individual) investors and coordinated (advised) investors, and their fund changes, separately. This identification is not arbitrary. Analysis carried out by the Swedish Pensions Agency suggests that a strong link exists between coordinated fund changes and financial advisors.

\subsection{Results on non-coordinated investors}

In this section we evaluate the investment performance of non-coordinated investors and relate it to their activity. We also establish causality, from activity to performance, and shed light on the portfolios and strategies these investors employ. 


\subsubsection{Investor activity and performance}

To investigate the relationship between activity and performance we first sort non-coordinated investors based on the number of fund changes they made in the one-year period prior to each return measurement day. We sort daily based on past activity to avoid reverse causality concerns, and we skip ten days between the date used to sort investors and each return measurement day to make sure that there are no price impact effects related to fund changes affecting our results.11 We then form three different calendar-time portfolios by equally weighting individual portfolios in each activity category. The first portfolio, labeled "inactive," includes individuals who did not make a fund change during the sorting period. The second portfolio, labeled "active," includes individuals who made at least one change but were not in the top decile of activity during the sorting period. The last portfolio, labeled "highly active," includes individuals in the top decile of activity in the sorting period.

Table III shows the composition of these three portfolios. The inactive (over the previous year) category includes $93.5 \%$ of the individuals in the sample, the active category includes $5.8 \%$ of the individuals in the sample, and the highly active category includes a small number of very active investors ( $0.6 \%$ of the individuals in the sample). This table also shows that there is a strong relationship between past trading activity and future trading activity, which is essential if we are to use past trading activity as an instrument for future trading activity. For instance, inactive investors, who do not make any changes in the sorting period, make an average of 0.05 changes per year in the measurement period, whereas highly active investors, who make an average of 8.17 changes per year in the sorting period, make 7.15 changes per year in the return measurement period. The correlation between the number of changes in the sorting and measurement periods is 0.64 , which is statistically significant at the $1 \%$ level.

To measure the investment performance of these three investor groups we rely on the

\footnotetext{
${ }^{11}$ In the Online Appendix we show that sorting investors based on the number of fund changes they made during our entire sample period leads to similar results.
} 
traditional risk-based approach. It is common in this literature to assume that the riskiness of the individual portfolios can be measured using the market, size, value, and momentum factors identified by Fama and French (1993) and Carhart (1997) The Fama-FrenchCarhart factors are also widely used to evaluate international portfolios, although there is less consensus about how to best build, and use, these factors in such a setting. Research by Hou, Karolyi, and Kho (2011) and Fama and French (2012) suggests that local (country or region) or international (including separate local and foreign components) versions of these factors do a better job in pricing local assets than purely global versions. In practice, however, researchers have variously used US domestic factors (e.g., Berk and van Binsbergen, 2015), factors constructed for each individual country (e.g., Ferreira, Keswani, Miguel, and Ramos, 2012), or regional factors (e.g., Cremers, Ferreira, Matos, and Stark, 2016) when evaluating international portfolios or funds.

Investors in the PPS have significant exposure to both Swedish and international funds: on average $40 \%$ of the equity portfolio and $86 \%$ of the fixed income portfolio of PPS investors is invested in funds with a focus on Sweden, with the rest of their investments distributed over the rest of the world. We therefore evaluate risk-adjusted performance using two different set of factors that capture mutual funds' investments in local bonds, and local and global stocks. The first, a hybrid Fama-French model (FFH) that includes the excess return of the Swedish equity market, the excess return of the world equity market, and separate Swedish and world value (HML), and size (SMB) factors, plus a factor capturing the excess return of the Swedish long maturity bond market over the risk free rate (OM Benchmark Total Swedish long bond index minus JP Morgan's one-month cash rate for Sweden) as factors ${ }^{13}$ The second, a hybrid

\footnotetext{
${ }^{12}$ In recent years, several papers have proposed new and additional risk factors (e.g., Novy-Marx, 2013; Asness, Frazzini, and Pedersen, 2014; Fama and French, 2015; Hou, Xue, and Zhang, 2015). However, the Fama-French-Carhart model remains widely used for performance evaluation.

${ }^{13}$ Our world factors are not foreign (i.e., ex-Sweden) as in Hou, Karolyi, and Kho (2011). However, Sweden is a relatively small country with a weight in the global portfolio of around $1 \%$. This suggests that results would be very similar if we were to work with ex-Sweden factors. Our factors could also be interpreted as investment opportunities available to investors, rather than risk factors (see Berk and van Binsbergen, 2015).
} 
Fama-French-Carhart model (FFCH) that extends the previous model by adding separate Swedish and world momentum factors in the spirit of Carhart (1997). These models use daily factors obtained from AQR's website (Sweden and world Fama-French-Carhart factors) and Datastream (JP Morgan's one-month cash rate and OM Benchmark Total Swedish long bond index) ${ }^{14}$

We follow the traditional calendar-time portfolio approach and estimate the following SURE system with OLS:

$$
\bar{r}_{c, t}=\alpha_{c}+\beta_{c}^{\prime} f_{t}+u_{c, t}, \text { for } c=1,2,3,
$$

where $\bar{r}_{c, t}$ is the cross-sectional average of the excess returns for investors in category $c$ on day $t, f_{t}$ is a vector of excess returns on benchmark factors (including two lags and two leads of each factor, as all models are estimated using a Dimson, 1979, correction to address the time zone mismatch in international portfolios), and $\beta_{c}$ is a vector of factor loadings for category $c$. We test if the alpha of category $c$ is different from zero, or if it is different from another category's alpha, using a Newey and West (1987) estimator of the covariance matrix of the full system.

Panel A of Table IV presents the average returns and alphas obtained by these three groups of investors. Returns and alphas are annualized by multiplying them by 252 (the average number of trading days in a year). The average return of the portfolio of investors who made no changes during the sorting period is $3.82 \%$ per year, compared to $6.86 \%$ per year for the portfolio of investors who made a few changes (activity deciles 1 to 9), and $12.57 \%$ per year for the portfolio of investors in the highest decile of activity. Fama-French

\footnotetext{
${ }^{14}$ Unlike Ferreira, Keswani, Miguel, and Ramos (2012) or Cremers, Ferreira, Matos, and Starks (2016) our unit of analysis is the individual portfolio, not mutual funds. These individual portfolios tend to have exposure to several countries at the same time, and this exposure also changes with time. This renders working with individual country factors infeasible, as we would need hundreds of factors for each group of individuals.
} 
and Fama-French-Carhart alphas from our hybrid factor models are also increasing in preevaluation period activity. For instance, annualized alphas from the FFCH factor model go from $-0.70 \%$ for the inactive portfolio to $7.56 \%$ for the highly active portfolio. A $t$-test of the difference between the most and least active categories indicates that these results are not only economically but also statistically significant.

The importance of fund changes in explaining the observed differences in performance is highlighted by the results of Panel B in the same table. Panel B of Table IV presents the performance that investors would have obtained if they had not made any changes to their portfolios. It also shows the $p$-values of a test of the difference between the actual and counterfactual alpha (reported in square brackets). We construct these counterfactual portfolios by discarding all active fund changes made by investors since they entered the system. The results show that performance is poorer when fund changes are discarded. For instance, we estimate a FFCH alpha of $2.09 \%$ per year for individuals in the active category. This alpha decreases to $-0.61 \%$ per year when no fund changes are kept (this is the alpha that these investors would have obtained if they had stayed with their initial fund allocation). The drop in portfolio performance once we exclude active fund changes is even more significant for individuals in the highly active category, from $7.56 \%$ per year to $0.30 \%$ per year. Even when excluding all active fund changes active investors would have outperformed inactive investors by $0.24 \%$ per year $(1.15 \%$ per year if we compare highly active investors to inactive investors), suggesting that individuals in the most active categories made better initial fund choices. However, this outperformance is much smaller than the $2.79 \%$ difference per year in actual FFCH alphas between these two groups of investors (8.26\% per year when comparing inactive to highly active investors). These results suggest that while active investors may be more capable investors to start with, most of their outperformance of inactive investors is achieved through their ability to actively and profitably change funds.

In the Online Appendix we explore the robustness of these results by using alternative 
specifications and benchmark models. We consider a daily default fund-based benchmark model (where the only benchmark is the default fund) and a model built from a set of regional equity and fixed income indexes (Asia-Pacific, Europe, North America, Sweden, and Emerging markets equity indexes, and Sweden and Global fixed income indexes), inspired by the approach advocated by Berk and van Binsbergen (2015). We also consider monthly (instead of daily) versions of our main two models, plus a series of alternative monthly models: a hybrid model that instead of using the book-to-market factors (global and Swedish) uses factors constructed from cash earnings to price $(\mathrm{CE} / \mathrm{P})$ portfolios, in the spirit of Hou, Karolyi, and Kho (2011); a model that extends the hybrid Fama-French-Carhart model by including separate Swedish and global quality minus junk factors, as in Asness, Frazzini, and Pedersen (2014); and a global six-factor model, including the three traditional Fama-French factors plus robust minus weak profitability and conservative minus aggressive investments factors, as in Fama and French (2015b), in addition to our bond factor. In all cases, riskadjusted returns are significantly increasing in the number of fund changes.

\subsubsection{Decomposing the performance of active and inactive investors}

In order to understand the performance differences between active and inactive investors we next explore in more detail the portfolios these different investors employ, and the contribution of fund changes to their performance. Table $\mathrm{V}$ shows the asset class and geographic concentration of the portfolios employed by investors in each activity group, the average number of funds in their pension portfolios, the average fees charged by the funds they invest in, and also how much these funds deviate, on average, from common benchmarks. We measure a fund's deviation from common benchmarks by using the $R$-squared of the fund against a set of broad market indexes (FTSE equity indexes for Asia-Pacific, Europe, North America, and Sweden; S\&P Emerging markets equity index; and OM Sweden fixed income benchmark and Barclays Capital Global Aggregate Bond index) in a multivariate 
regression framework, or the FFH model. This table provides a static characterization of the portfolios of active and inactive investors. It shows that active and inactive investors have a tendency to invest in different types of funds. While the most active investors invest heavily in emerging market equity and fixed income funds, inactive investors show a stronger tilt towards balanced funds (including the default). More active investors also tend to hold a larger number of funds at any point in time, and invest in funds that are more specialized and charge higher fees.

The performance differences between the different investor groups could in principle be explained by their tendency to invest in different asset classes and geographic regions. To explore this possibility we perform a return decomposition analysis. Following Brinson, Hood, and Beebower (1986) we decompose daily returns into four components, which we compute using the same principles employed by Daniel, Grinblatt, Titman, and Wermers (1997) but applied to funds rather than stocks. As an arithmetic identity, for each investor $i$ and day $t$ :

$$
\begin{aligned}
\sum_{j=1}^{N} w_{j, t-1} r_{j, t} \equiv \underbrace{\sum_{j=1}^{N} w_{j, t-253}\left(r_{j, t}-b_{j, t}\right)}_{\mathrm{AFS}}+ & \underbrace{\sum_{j=1}^{N}\left(w_{j, t-1}-w_{j, t-253}\right)\left(r_{j, t}-b_{j, t}\right)}_{\mathrm{FST}} \\
& +\underbrace{\sum_{j=1}^{N}\left(w_{j, t-1}-w_{j, t-253}\right) b_{j, t}}_{\mathrm{ACT}}+\underbrace{\sum_{j=1}^{N} w_{j, t-253} b_{j, t}}_{\mathrm{AAC}},
\end{aligned}
$$

where $w_{j, t-1}$ is the weight of fund $j$ in investor $i$ 's portfolio at the end of day $t-1, r_{j, t}$ is the day $t$ return of fund $j, b_{j, t}$ is the day $t$ return of fund $j$ 's benchmark, and $N$ is the total number of funds in the sample. For each fund, the benchmarks returns used in this decomposition are computed as the equally weighted average returns of all funds in the PPS that belong to the same asset class and geographic region as the fund, thus satisfying the requirement that benchmarks should be investable (see Table $\mathrm{V}$ for the list of asset classes 
and regions used in the decomposition).

Total individual returns are equal to the sum of four different components: Average Fund Selection (AFS), Fund Selection Timing (FST), Asset Class Timing (ACT), and Average Asset Class returns (AAC). The precise definition of each of these components is contained in equation (2). The AFS component measures the excess returns earned by an investor due to that investor's tendency to choose certain funds within an asset class and region. Note that by lagging fund weights by one year, as in Daniel, Grinblatt, Titman, and Wermers (1997), we eliminate returns due to timing of funds (within an investment category). The FST component measures the ability of an investor to time the investment in different funds within an asset class and region 15 The ACT component measures an investor's success at timing the different asset classes. Finally, the AAC component measures the returns earned by an investor due to that investors tendency to invest in funds within certain asset classes and geographic regions. The sum of the first three of these measures (AFS + FST + ACT) is what Daniel, Grinblatt, Titman, and Wermers (1997) consider true investment performance, as opposed to compensation for risk taking (AAC).

Panel A of Table VI presents the return decomposition for all non-coordinated individuals, as well as for the inactive, active, and highly active groups of individuals separately. Results in this table suggest that the difference in performance between (highly) active and inactive investors is not the result of these investors investing in different asset classes or geographic regions. Average asset class returns are $4.14 \%$ and $4.80 \%$ per year for inactive and highly active investors, respectively. This is consistent with results obtained from factor models that use regional equity and fixed income benchmarks as factors (reported in the Online Appendix) and together indicate that static investments in emerging markets, fixed

\footnotetext{
${ }^{15}$ Daniel, Grinblatt, Titman, and Wermers (1997) group the AFS and FST components, $\sum_{j=1}^{N} w_{j, t-1}\left(r_{j, t}-\right.$ $b_{j, t}$ ), into a single Fund Selection component (Characteristic Selectivity measure, in the terminology of Daniel, Grinblatt, Titman, and Wermers, 1997). FST, however, has both fund selection and a timing characteristics. Brinson, Hood, and Beebower (1986) and Blake, Lehmann, and Timmermann (1999) consider it a separate category (separate from fund selection).
} 
income or any other asset class cannot explain the return differences we observe ${ }^{16}$ Most of active investors' superior performance comes instead from asset class timing and, to some extent, fund selection timing. For highly active investors, the ACT component stands at $4.77 \%$ per year and is the largest and only individually significant component of their return decomposition. For inactive (over the previous year) investors the ACT component is only $0.04 \%$ per year. Adding up the two timing components, ACT and FST, results in values of $6.65 \%$ and $-0.06 \%$ per year for highly active and inactive investors, respectively. Differences between these two groups of investors are, in both cases, statistically significant. Highly active investors also seem marginally better at selecting funds within an asset class or investment category. The difference in average fund selection component between highly active and inactive investors is $1.39 \%$ per year, increasing to a statistically significant $3.37 \%$ per year if we consider it together with the other fund selection (and timing) component $($ AFS + FST), as Daniel, Grinblatt, Titman, and Wermers (1997) do.

A concern about the interpretation of this decomposition is that it represents only performance evaluation relative to benchmarks with an implicit beta of unity. This practice might conceal more substantial cross-sectional variations in risk-adjusted returns relative to alternative benchmarks. It turns out that this is not the case; Panel B of Table VI shows that risk adjustment using the FFCH model changes the magnitude of these components but not significantly so. The timing component is still the largest, and highly statistically significant, as is the difference in timing components between inactive and highly active investors. Thus, highly active investors not only choose well but, more importantly, they successfully time their choices to obtain superior returns. ${ }^{17}$

\footnotetext{
${ }^{16}$ That outperformance cannot be attributed to a one-time shift in holdings towards any asset class either. Highly active investors holdings have fluctuated significantly over our sample period with no noticeable trend (see Online Appendix for more details).

${ }^{17}$ Highly active investors invest in high risk funds (emerging market equity) and low risk ones (fixed income), but on average their portfolio is not riskier, or more volatile, than that of inactive investors. See the Online Appendix for an analysis of the volatility and Sharpe ratios of different investor groups.
} 
Given the importance of timing in the decisions of active investors and to further investigate the impact of fund changes on performance, we next look at the time profile of the contribution of portfolio changes to the observed results. For this purpose we form two different portfolios for each group of investors. The "new" portfolios follow the performance of the funds chosen by each individual investor who makes a portfolio change for either one week, one month, six months, one month ignoring the first week, or six months ignoring the first month. The "old" portfolios follow the performance of the funds discarded by each individual during similarly defined periods. Each time an investor makes a portfolio change, we place the portfolio of funds the investor chose in our calendar-time new portfolio. Similarly, we place the portfolio of funds the investor discarded in our calendar time old portfolio. Funds are kept in these portfolios for a pre-determined length of time. The new and old portfolios are formed by weighting each individual fund portfolio equally. Funds, however, receive different weights depending on their weights on the individual portfolios. Our strategy of mimicking the portfolio changes of individual investors is similar to the transaction-based calendar-time portfolios employed by Seasholes and Zhu (2010).

The first column of Table VII presents the average returns. The remaining columns present FFH and FFCH alphas for each of these portfolios. For all three groups of investors, the new portfolios outperform the old portfolios over all the horizons we study, and other than in the five-month period starting a full month after the portfolio change, they do so significantly. For instance, for highly active investors the new portfolio returns exceed the old portfolio returns by an annualized $4.67 \%$ in the week following the portfolio change; and by an annualized $3.74 \%$ in the month following that change. The difference in FFCH alphas are $4.75 \%$ and $3.71 \%$ per year for these two portfolios. The differences are still large six months after the portfolio change, although they are no longer statistically significant if we exclude the first month after the change (i.e., when looking at the performance between days +31 and +180 of the portfolio change). Something similar happens with inactive (over the 
previous year) investors. Their newly chosen portfolios tend to do significantly better than their old portfolios. However, the performance of inactive investors' new (and old) portfolios is not as good as the performance of the new (and old) portfolios of the most active investors in our sample. Inactive investors also make far fewer changes, thus hardly benefiting from activity overall ${ }^{18}$

The results in Table VII also reveal that the bulk of the benefits from a portfolio change are obtained in the first month after the change. After that the outperformance of the new portfolio weakens, but it is not reversed. However, the outperformance of the new portfolio is not just a matter of a few days and cannot therefore be attributed to investors being able to trade at stale prices 19 There is actually almost no difference between the performance of new portfolios in the first month after the portfolio change (the mean return for all investor groups is $13.88 \%$; the FFCH alpha is $9.58 \%$ ) and their performance in weeks two to four (the mean return for all investor groups is $13.47 \%$; the FFCH alpha is $9.18 \%$ ).

By looking at the performance of the portfolios chosen and discarded by individual investors over different horizons we can also see why highly active investors perform so well. These investors not only choose well, but also hold the funds they choose during the period they are more likely to outperform. This point is stressed in Panel B of Table VII, which shows the estimated holding period of inactive, active, and highly active investors based on a parametric Weibull duration model.

Finally, Table VII also helps bridge the gap between our results and those of the smart money literature. Keswani and Stolin (2008), the closest study to ours, find that high net flow funds outperform low net flow funds. Using monthly data on exact fund flows, they

\footnotetext{
${ }^{18}$ Not only the newly chosen portfolios but also the old portfolios discarded by highly active investors exhibit positive abnormal returns. This is reasonable. For highly active investors, a discarded portfolio is a portfolio that was "new" only a short time before. Inactive investors' old portfolios, chosen long before, do not follow this pattern. Their alphas are negative, or close to zero, in all the periods we study.

${ }^{19}$ According to our conversations with officers at the Swedish Pensions Agency, fund changes are executed two days after they are requested by investors, making late trading virtually impossible.
} 
report a difference in risk-adjusted returns between positive and negative net retail flow funds of $1.65 \%$ per year. The results we report in Table VII are at least twice as large. The average difference in FFCH alphas between new (inflow) and old (outflow) funds across all activity categories in the month following the change is $3.61 \%$ (averages for all investors are reported in the Online Appendix). There are several reasons for this. First, as shown in Table VII. missing the first few weeks after the change, as a monthly analysis is likely to do, will result in lower estimates for the smart money effect. This is similar to what happens when going from a monthly (e.g., Keswani and Stolin, 2008) to a quarterly analysis (e.g., Sapp and Tiwari, 2004), as the smart money effect seems to decay with time (see also Frazzini and Lamont, 2008). Second, while we concentrate on active fund changes (that result in active flows), most smart money studies rely on actual or estimated flows that typically include flows that are automatic in nature (e.g., periodic payments into pension or 401(k) accounts that are channeled towards funds selected years before, assets being moved from one fund to another as funds merge or are being withdrawn from retirement menus). To the extent that smart decisions have a significant timing component, considering automatic flows (the result of old decisions) together with active ones (resulting from new decisions) is likely to reduce the smartness of the average flow. Finally, our funds are more heterogeneous (including funds from different asset classes) than the set of funds typically studied in the smart money literature, and it might be possible to do better when selecting from a more diverse pool of funds.

Working with individual portfolios tracked at a daily frequency, rather than aggregate flows, allows us to make a number of contributions to the smart money literature. First, a more precise measurement of smart money effects, by using detailed information of when investors buy and sell their fund shares. Second, an estimation of holding periods; their importance for investors' performance highlighted by Frazzini and Lamont's (2008) finding that the smart money effect tends to be confined to relatively short horizons, while at 
longer horizons a dumb money effect dominates. Finally, it also allows us to document the heterogeneity in investor smartness: while many investors look smart if we consider their performance shortly after the portfolio change, only a fraction of them are truly smart when we take into account their actual holding periods.

\subsubsection{Performance chasing and its impact on investor returns}

As we document in the previous section, a significant fraction of the abnormal returns seems to occur shortly after a portfolio change. This could indicate that active investors are exploiting the sort of short-term persistence in fund performance identified by Bollen and Busse (2004) (see also Mamaysky, Spiegel and Zhang, 2008, and Lou, 2012). To explore this possibility we look at the proportion of top decile funds in investors' portfolios.

Panel A of Table VIII shows the average percentage of an individual portfolio invested in funds which, on the day of the portfolio change, are ranked in the top decile of past performance. We base daily past performance deciles on fund returns during the one-, three, six-, or twelve-month period ending three days before the decile formation date. The three-day gap allows us to account for the delay in executing transactions in the PPS. The results in Panel A of Table VIII suggest that investors are disproportionately choosing top decile funds when making portfolio changes. This is true of highly active, active, and inactive investors. For instance, highly active investors invested on average $51.4 \%$ of their portfolios on funds ranked in the top decile of performance measured over the six-month period prior to their portfolio change. The percentages are similar, but somewhat smaller, at $51.0 \%$ and $48.8 \%$ respectively, if we concentrate instead on prior three- or twelve-month performance. At the same time investors that were inactive over the previous year invested on average $26.5 \%$ of their portfolios on funds ranked in the top decile of performance measured over the six-month period prior to their portfolio change. This is less than active and highly active investors invest in top decile funds but still more than it would be expected if they were 
switching funds at random.

The difference between highly active and inactive investors is more marked when we look at the percentage of the individual portfolio that is invested in funds ranked in the top decile of past performance across the entire sample (not just after the portfolio change). Panel B of Table VIII shows that highly active investors keep a high proportion of top decile funds in their portfolios at all time: on average $47.7 \%$ of their portfolios is invested on funds in the top decile of previous six-month performance. The proportion of the inactive investors' portfolios invested in top decile funds, however, drops significantly when we look at the entire time series rather than the day following their portfolio changes: from $26.5 \%$ to $4.3 \%$ for deciles formed based on prior six-month performance. Thus, while all investors tend to choose funds that have performed well in the recent past, only highly active investors consistently keep a high proportion of recent good past performers in their portfolios.

We next study whether investors especially benefit from investing in funds with good recent past performance by decomposing the realized returns obtained by each individual into two components: the returns earned by an investor due to his or her tendency to invest in funds in certain past performance deciles and the returns obtained on top (or below) that strategy. We label the first of these components as Average performance chasing returns, and the second as the Excess over performance chasing strategy.

We define the Average Performance Chasing returns as $\sum_{j=1}^{N} w_{j, t-253} b_{j, t}$, where $w_{j, t-253}$ is the weight of fund $j$ in investor $i$ 's portfolio at the end of day $t-253$ and $b_{j, t}$ is the day $t$ return of fund $j$ 's benchmark, where the benchmark is the average return of all funds classified in the same past performance decile the fund was ranked a year ago. That is, these are the returns an investor would have obtained if he or she had invested in funds classified in the same past performance fund deciles he or she invested in a year before. In this decomposition we work with deciles formed based on past performance over the previous six months. As the results in Table VIII indicate this is the most common performance chasing horizon for 
PPS investors. The Excess over performance chasing strategy, in turn, equals the difference between realized returns and Average performance chasing returns.

Table IX] presents the results of this exercise. By investing in funds in the same past performance deciles as highly active investors do on average, an investor in the PPS would have been able to obtain an annual return of $7.58 \%$. By comparison, if that investor had mirrored the performance chasing of inactive investors, he or she would have obtained a $3.61 \%$ annual return instead. The $3.97 \%$ difference in returns between these two past performance chasing strategies accounts for $45 \%$ of the difference between the returns obtained by highly active and inactive investors. The remaining $55 \%$ of the difference reflects the outperformance - over and above a simple return chasing strategy - which highly active investors achieve thanks to fund selection and switching. A similar picture emerges if we further risk-adjust the elements of the decomposition by using the hybrid Fama-French-Carhart regression model (see Panel B of Table IX).

Overall, these results suggest that some, but not all, of active investors' outperformance can be explained by their tendency to pursue strategies that benefit from the short-term persistence in fund performance. Importantly, they do this in a context where these strategies seem most economical. As Bollen and Busse (2004) note, short-term persistence would allow an astute investor to predict future performance based on past results and potentially profit from it. Bollen and Busse (2004), however, are adamant that in most cases transaction costs and taxes would offset the benefits of such strategies. The PPS, by freeing investors from these costs, allows them to substantially profit from these opportunities.

\subsubsection{Are active investors different?}

Men tend to be more active than women, and there is also a positive relationship between activity and income (or pension rights, see Table X). Some of these individual characteristics may also be associated to performance. To isolate the contribution of activity to individ- 
ual performance, we next study how the activity-performance relationship changes when controlling for a set of demographic characteristics.

For this purpose we use the following panel data regression $(t=1, \ldots, T$ and $i=1, \ldots, N)$ to estimate a factor model, conditioning on a set of investor characteristics:

$$
r_{i, t}=\left(\alpha+\alpha_{z}^{\prime} z_{i, t}\right)+\left(\beta+\beta_{z}^{\prime} z_{i, t}\right)^{\prime} f_{t}+\varepsilon_{i, t}
$$

where $r_{i, t}$ is the excess return for individual $i$ on day $t$, and where we condition on the investor characteristics $z_{i, t}$ (investor activity, which we measure using a dummy variable for each activity category, age, gender, and pension rights, which is an income proxy). We estimate this panel regression using Driscoll and Kraay's (1998) covariance estimator, thus accounting for heteroskedasticity as well as cross-sectional and serial correlations in the error terms. As discussed in Hoechle, Schmid, and Zimmermann (2015) and our Online Appendix, this panel regression nests several other methods, including the traditional calendar time portfolio approach we use in the rest of the paper. It is, however, better suited to deal with multiple (and continuous) investor characteristics than the portfolio approach. The point estimates of $\alpha_{z}$ in this regression measure how performance depends on the various investor characteristics, including investor activity.

Panel A of Table $\mathrm{X}$ presents these results. Although arranged differently, the results in specification I and III, where individual returns are regressed on a constant, a set of dummies for the activity categories, the factors included in the FFH or FFCH models, and interaction terms between factors and activity categories, are identical to those reported in Table IV ${ }^{20}$ The active investor category has a $2.79 \%$ higher FFCH alpha than the inactive category

\footnotetext{
${ }^{20}$ We estimate this panel using weighted least squares to replicate the results of the portfolio approach (see Hoechle, Schmid, and Zimmermann, 2015). The panel naturally gives the same weight to each individual observation whereas the portfolio method gives the same weight to each daily observation. Thus we re-weight each observations in the panel regression so as to attach the same weight to each day of data. Estimation via OLS gives very similar results, as the panel is nearly balanced.
} 
(captured by the constant), whereas the highly active investor category has a $8.27 \%$ higher FFCH alpha than the inactive category. The performance differences between active and inactive investors are statistically significant. Adding age, gender, and an income proxy to the regression does not affect the shape of the relationship between activity and performance (see specifications II and IV). Thus, while active investors may be different along a number of dimensions, it is not these demographic differences that explain their performance. Table $\mathrm{X}$ also shows that men significantly outperform women in our sample (in contrast to the classic result in Barber and Odean, 2001).

\subsection{Coordinated investors}

We next turn our attention to coordinated investors. We attribute coordinated changes to financial advisors who give recommendations and manage portfolios on a discretionary basis. We identify financial advisors by the portfolio changes they do.

To study the performance of coordinated investors we construct a portfolio that includes all coordinated investors in our sample. The first line of Table XI shows the performance of this portfolio (gross of financial advisor fees). This portfolio has an average return of $3.78 \%$ per year and an alpha from the FFH model of $-0.62 \%$ per year, similar to the aggregate performance of inactive non-coordinated investors (reported in Table IV). Since it is unlikely that coordinated individuals employed a financial advisor during the entire sample period, we also construct a portfolio where individuals are included only during the time period they are classified as coordinated. We define the coordinated period as: 1) starting on the date of the portfolio change immediately preceding the first multiple change the individual makes, and 2) ending three months after the last multiple change made by the individual. ${ }^{21}$ This

\footnotetext{
${ }^{21}$ The first of these conditions intends to capture the move from the individually chosen portfolio to the advisors preferred portfolio. The latter puts a horizon beyond which we assume individuals have stopped using the advisor if there are no further coordinated changes. Multiple changes are defined as changes that are identical (same funds of origin, same funds of destination, and same change date) to those executed by 250 or more individuals in the PPS. In the Online Appendix we show similar results using alternative
} 
portfolio has an average return, before any financial advisor fees, of $5.21 \%$ per year and an alpha from the FFH model of $0.61 \%$ per year. The aggregate performance of coordinated investors is therefore better when measured during their coordinated period, but differences in average returns and alphas between this portfolio and that of inactive investors, although positive, are not statistically significant, as shown in Panel B of Table XI.

Financial advisors, however, charge a fee for their advice. This fee is not deducted from the investors' returns but paid outside the pension system. The fee typically amounts to between $1 \%$ and $2 \%$ of assets under management per year, which would significantly lower the actual performance. Table XI shows results for a hypothetical fee of $1.5 \%$ of assets under management. Under such fees individuals who resort to financial advisors seem to do as well, during the period the advisory relationship is assumed to run, as inactive individuals do on an after fee basis. The average difference between the two is a non-statistically significant $0.05 \%$ per year (see Panel B of Table XI for a formal comparison) ${ }^{22}$

Overall, our findings suggest that individuals who resort to financial advisors do not perform better than those who manage their retirement accounts themselves or who are assigned to the default fund. They do not perform significantly worse either. In that sense our results for financial advisors are not as bleak as the picture painted by the nascent literature on this topic (e.g., Bhattacharya, Hackethal, Kaesler, Loos, and Meyer, 2012; Hackethal, Haliassos, and Jappelli, 2012; and Mullainathan, Nöth, and Schoar, 2012).

definitions of multiple changes.

${ }^{22}$ Average differences likely mask some heterogeneity among advisors. For instance, in the Online Appendix we report that $65.6 \%$ of individuals that resort to a financial advisor underperform inactive non-coordinated investors, on an after-fee basis, even when average FFCH alphas for these two groups of investors is virtually identical. 


\section{The dark side of activity}

Investors that buy or sell shares in individual stocks have to pay brokerage fees and absorb bid-ask spreads and the price impact of their trades. That is, investors who trade, not others, pay their entry and exit costs. As Chordia (1996) notes, this is not the case when they invest through mutual funds. Mutual funds are required by law to pay a pro-rata share of the net asset value of the fund to each redeeming investor. Due to this, investors who redeem their mutual fund shares are likely to impose externalities on those that do not. These externalities arise because the liquidation of securities results in costs (brokerage fees, bid-ask spreads, and price impact of trading) that compromise fund performance. These costs are borne by the fund, not by the investor who triggered them, and as suggested in previous studies their impact on performance could be substantial (e.g., Edelen, 1999; Greene and Hodges, 2002; and Coval and Stafford, 2007).

To assess whether active investor flows affect fund performance we follow Chen, Goldstein, and Jiang (2010) and run regressions of a fund's abnormal return on its lagged abnormal returns and various measures of flows:

$$
\operatorname{ar}_{j, t}=\alpha_{j}+\sum_{k=1}^{10} \beta_{k} \operatorname{ar}_{j, t-k}+\gamma \text { Outflow }_{j, t}+\delta \operatorname{Inflow~}_{j, t}+\epsilon_{j, t}
$$

where $\operatorname{ar}_{j, t}$ is the daily abnormal return of fund $j$ on day $t$, defined as the sum of the intercept and the residual in the FFH seven-factor model regression described in Section 4.1.1. Outflow ${ }_{j, t}$ is a measure of the fund's relative outflow generated by the entire population of PPS investors; and Inflow $j, t$ is a measure of the fund fund's relative inflow from pension investors. Relative outflows (inflows) are expressed as a fraction of average outflows (inflows) for each particular fund. We use average flows as a proxy of a fund's capacity to handle outflows and inflows. In the Online Appendix we show results for alternative definitions of relative flows. A significant coefficient estimate of $\gamma(\delta)$ would show that outflows (inflows) 
affect a fund's future return beyond what is predicted by past returns.

The abnormal return and flows are contemporaneous in this specification. However, it is important to note that the decision to make a fund change is taken two to three days before the actual flow occurs.23 This means that even if the flow is contemporaneous, it is driven by decisions taken previously, making reverse causality explanations less likely. The regression model is estimated by pooling all data and includes fund fixed effects. Effectively, we only use the time series to identify the return-flow relationship. To account for the cross-sectional correlations in the error terms we use the Driscoll and Kraay (1998) covariance estimator.

Panel A of Table XII presents the results for equity funds over the 2000 to 2010 period ${ }^{24}$ The focus of our discussion is the coefficient of the flow measures. Specifications I-IV use two dummy variables, one for outflows and one for inflows, to capture whether relative outflows and inflows are larger than certain thresholds on a given day. For instance, in specification II the outflow (inflow) dummy variable assumes a value of one if outflows (inflows) are ten times larger than the average outflows (inflows) of the fund over the time series. Such extreme flows happen in $1.24 \%(1.82 \%)$ of the observations (see Panel $\mathrm{C}$ of the table). The effect of an outflow of this size is an abnormal return of -6 basis points. The effect becomes stronger as we consider more extreme flows. The point estimates in specification IV indicate that outflows that are thirty times larger than the average outflow of the fund, something that happens on $0.28 \%$ of the fund-days, lead to abnormal returns of -9.5 basis points. Extreme flows sometimes cluster and occur two or more days in a row. For instance, for specification IV, $0.05 \%$ of the days belong to two-day clusters with extreme outflows, which doubles the economic effect from -9.5 to -19 basis points. There are also three-day and four-day clusters on $0.02 \%$ and $0.01 \%$ of days, tripling and quadrupling the economic effect.

\footnotetext{
${ }^{23}$ This is because the Swedish Pensions Agency executes fund changes two days after they are requested by investors.

${ }^{24}$ We find little price effect on bond funds. The majority of these funds are invested in relatively liquid money market or government securities.
} 
To explore the long-term impact of these flows on performance we estimate a two-equation VAR system. In the first equation, abnormal returns depend on ten lags of itself and contemporaneous and lagged (also ten lags) outflow and inflow dummy variables. In the second equation, relative net flows depend on ten lags of itself and ten lags of abnormal returns. Each of these two equations include fund fixed effects. These equations define an identified structural non-linear VAR: contemporaneous flows affect abnormal returns, but not the other way around. This VAR structure allows us to capture the rich dynamics of returns and flows.

Panel B of Table XII shows the cumulative return responses, implied by the VAR, to outflow (and inflow) shocks of different sizes. In all cases the cumulative return responses to outflow shocks, ten and twenty days after the shocks, are of similar magnitude to the contemporaneous response. These cumulative responses, are also highly significant, indicating that the impact is persistent (i.e., not just the result of temporary price pressure).

In all these specifications the coefficients for outflows are strongly significant. Inflows, on the other hand, do not have a noticeable impact on abnormal returns. The asymmetries in the impact of inflows and outflows on NAVs likely reflect the asymmetries that mutual funds face in how they can respond to them. A mutual fund with a large inflow can allocate new money in ways to minimize the price impact of their trades. It can even allocate it to cash, thus also limiting direct trading costs. Often, the fund can mitigate a potential cash drag by taking a long position in index futures (to at least gain some market exposure). A mutual fund with an outflow does not have the same opportunity. It can use its cash to some extent, but for a large outflow it needs to liquidate parts of its risky assets. The investment statutes typically do not allow for a short futures position. As a result, flows are usually more costly when they necessitate sales rather than purchases (see Christoffersen, Keim, and Musto, 2008).

These results provide evidence that extreme outflows affect fund NAVs for all investors. 
Yet, the investors that trigger these flows bear only a small part of those costs. The same happens with the administrative costs that result from fund changes 25 These costs are imposed by a relatively small fraction of investors but borne by the system as a whole, and shared equally by all investors (active or not). Financial advisors likely exacerbate this problem by making fund changes less individually costly, and therefore more frequent, and by contributing to the coordination of those changes. As shown in Panel C of Table XII. more than $90 \%$ of the investors behind the largest fund outflows/inflows episodes in our sample (those that result in flows that are at least thirty times larger than average fund flows) are coordinated investors.

\section{Concluding remarks}

Investor inactivity in self-directed defined contribution plans is frequently a source of concern for pension authorities. But, is inactivity a problem for investors, or is activity beneficial to them? Our study suggest that while some individual investors benefit from their activity, the fund flows generated by this activity affect mutual funds' net asset values negatively for all investors.

We consider detailed data of individuals' choices and changes of mutual funds in the Swedish Premium Pension System from 2000 to 2010. We find that active investors earn significantly higher returns than inactive investors. This is not because active investors take more risk, as the difference in risk-adjusted returns is of a similar magnitude. Instead, a performance decomposition analysis reveals that most of the outperformance of active investors results from these investors successfully timing their investments in funds and

\footnotetext{
${ }^{25} \mathrm{~A}$ more subtle cost is the exclusion of illiquid investment options from the fund menu in the PPS. Consider an illustration of this issue. On September 8, 2008, the pensions agency had to liquidate a position of SEK 55 million in Danske Fund Baltic. In addition to have an impact on the value of the shares for the remaining shareholders, the fund manager claimed that it would be impossible to liquidate all those shares in the usual time span (two-three days for foreign funds). In the end, the transaction took one month to complete and the fund was later withdrawn from the system by Danske Bank.
} 
asset classes. The fact that active investors tend to invest in recent past winners suggests also that they may be taking advantage of the kind of short-term persistence in fund returns identified by Bollen and Busse (2004), in a context where the absence of transaction costs makes it economical to do so. However, the high activity of a minority of individuals seems to burden the pension system. There are several costs (e.g., administrative, trading, and liquidity provision) associated with executing fund changes in the system, yet active investors do not have to pay them. Financial advisors, by contributing to coordinate investments and redemptions, exacerbate these costs.

Our results speak primarily about the relationship between investor activity and performance. They also relate to important pension design issues: How much freedom should individual investors have to choose and change funds? Should fees be charged that either discouraged costly short-term investments or compensated the fund for its transaction costs? $?^{26}$ Should financial advisors and account managers be restricted in their operations? We touch upon these issues in our study, but they all merit further future research.

\footnotetext{
${ }^{26}$ In the US, for instance, the SEC encourages redemption fees, particularly for short-term holding periods (see Greene, Hodges, and Rakowski, 2007), but this is not the case in the Swedish Premium Pension System.
} 


\section{References}

Agnew, Julie, Pierluigi Balduzzi, and Annika Sundén, 2003, Portfolio choice and trading in a large 401(k) plan, American Economic Review 93, 193-215.

Alexander, Gordon J., Gjergji Cici, and Scott Gibson, 2007, Does motivation matter when assessing trade performance? An analysis of mutual funds, Review of Financial Studies $20,125-150$.

Asness, Clifford S., Andrea Frazzini, and Lasse H. Pedersen, 2014, Quality minus junk, Working paper.

Barber, Brad M., and Terrance Odean, 2000, Trading is hazardous to your wealth: The common stock investment performance of individual investors, Journal of Finance 55, 773-806.

— 2001, Boys will be boys: Gender, overconfidence, and common stock investment, Quarterly Journal of Economics 116, 261-292.

— 2002, Online investors: Do the slow die first?, Review of Financial Studies 15, $455-487$.

Benartzi, Shlomo, and Richard H. Thaler, 2001, Naive diversification strategies in defined contribution savings plans, American Economic Review 91, 79-98.

— 2007, Heuristics and biases in retirement savings behavior, Journal of Economic Perspectives 21, 81-104.

Berk, Jonathan B., and Jules H. van Binsbergen, 2015, Measuring skill in the mutual fund industry, Journal of Financial Economics 118, 1-20.

Bhattacharya, Utpal, Andreas Hackethal, Simon Kaesler, Benjamin Loos, and Steffen Meyer, 2012, Is unbiased financial advice to retail investors sufficient? Answers from a large field study, Review of Financial Studies 25, 975-1032.

Blake, David, Bruce N. Lehmann, and Allan Timmermann, 1999, Asset allocation dynamics and pension fund performance, Journal of Business 72, 429-461.

Bollen, Nicolas P.B., and Jeffrey A. Busse, 2004, Short-term persistence in mutual fund performance, Review of Financial Studies 18, 569-597.

Brinson, Gary P., L. Randonlph Hood, and Gilbert L. Beebower, 1986, Determinants of portfolio performance, Financial Analysts Journal 51, 39-48.

Carhart, Mark M., 1997, On persistence in mutual fund performance, Journal of Finance 52, 57-82. 
Chen, Qi, Itay Goldstein, and Wei Jiang, 2010, Payoff complementarities and financial fragility: Evidence from mutual fund outflows, Journal of Financial Economics 97, 239262.

Chetty, Raj, John N. Friedman, Søren Leth-Petersen, Torben Heien Nielsen, and Tore Olsen, 2014, Active vs. passive decisions and crowd-out in retirement savings accounts: Evidence from Denmark, Quarterly Journal of Economics 129, 1141-1219.

Choi, James J., David Laibson, Brigitte C. Madrian, and Andrew Metrick, 2002, Defined contribution pensions: Plan rules, participant decisions, and the path of least resistance, in James Poterba, ed.: Tax Policy and the Economy . pp. 67-113 (MIT Press: Cambridge, M.A.).

Choi, James J., David Laibson, and Andrew Metrick, 2002, How does the internet affect trading? Evidence from investor behavior in 401(k) plans, Journal of Financial Economics 64, 397-421.

Chordia, Tarun, 1996, The structure of mutual fund charges, Journal of Financial Economics 41, 3-39.

Christoffersen, Susan E.K., Donald B. Keim, and David K. Musto, 2008, Valuable information and costly liquidity: Evidence from individual mutual fund trades, Working Paper, McGill University and University of Pennsylvania.

Coval, Joshua, and Erik Stafford, 2007, Asset fire sales (and purchases) in equity markets, Journal of Financial Economics 86, 479-512.

Cremers, Martijn, Miguel A. Ferreira, Pedro Matos, and Laura Starks, 2016, Indexing and active fund management: International evidence, forthcoming in Journal of Financial Economics.

Cronqvist, Henrik, and Richard H. Thaler, 2004, Design choices in privatized social-security systems: Learning from the Swedish experience, American Economic Review, Papers and Proceedings 94, 424-428.

Cuevas, Conrado, and Dan Bernhardt, 2016, The pied piper of pensioners, Working paper, University of Warwick.

Da, Zhi, Borja Larrain, Clemens Sialm, and Jose Tessada, 2016, Coordinated noise trading: Evidence from pension fund reallocations, National Bureau of Economic Research, WP No. 22161.

Dahlquist, Magnus, Ofer Setty, and Roine Vestman, 2016, On the asset allocation of a default pension fund, Working paper, Stockholm School of Economics. 
Daniel, Kent, Mark Grinblatt, Sheridan Titman, and Russ Wermers, 1997, Measuring mutual fund performance with characteristic-based benchmarks, Journal of Finance 52, 10351058.

Dimson, Elroy, 1979, Risk measurement when shares are subject to infrequent trading, Journal of Financial Economics 7, 197-226.

Driscoll, John, and Aart Kraay, 1998, Consistent covariance matrix estimation with spatially dependent panel data, Review of Economics and Statistics 80, 549.560.

Edelen, Roger, 1999, Investor flows and the assessed performance of open-end mutual funds, Journal of Financial Economics 53, 439-466.

Fama, Eugene F., and Kenneth R. French, 1993, Common risk factors in the returns on stocks and bonds, Journal of Financial Economics 33, 3-56.

— 2012, Size, value, and momentum in international stock returns, Journal of Financial Economics 105, 457-472.

— , 2015a, A five-factor asset pricing model, Journal of Financial Economics 116, 1-22.

— , 2015b, International tests of a five-factor asset pricing model, Working paper, University of Chicago and Darthmouth College.

Ferreira, Miguel A., Aneel Keswani, Antonio F. Miguel, and Sofia B. Ramos, 2012, The determinants of mutual fund performance: A cross-country study, Review of Finance 17, $483-525$.

Foerster, Stephen, Juhani T. Linnainmaa, Brian T. Melzer, and Alessandro Previtero, 2015, Retail financial advice: Does one size fit all?, forthcoming in Journal of Finance.

Frazzini, Andrea, and Owen Lamont, 2008, Dumb money: Mutual fund flows and the cross section of stock returns, Journal of Financial Economics 88, 299-332.

Gennaioli, Nicola, Andrei Shleifer, and Robert W. Vishny, 2015, Money doctors, Journal of Finance 70, 91-114.

Greene, Jason T., and Charles W. Hodges, 2002, The dilution impact of daily fund flows on open-end mutual funds, Journal of Financial Economics 65, 131-159.

— , and David A. Rakowski, 2007, Daily mutual fund flows and redemption policies, Journal of Banking and Finance 31, 3822-3842.

Gruber, Martin, 1996, Another puzzle: The growth in actively managed mutual funds, Journal of Finance 51, 783-810.

Hackethal, Andreas, Michael Haliassos, and Tullio Jappelli, 2012, Financial advisors: A case of babysitters?, Journal of Banking and Finance 36, 509-524. 
Hoechle, Daniel, Marcus M. Schmid, and Heinz Zimmermann, 2015, Decomposing performance, Working paper, University of St. Gallen.

Hou, Kewei, G. Andrew Karolyi, and Bong-Chan Kho, 2011, What factors drive global stock returns?, Review of Financial Studies 24, 2527-2574.

Hou, Kewei, Chen Xue, and Lu Zhang, 2015, Digesting anomalies: An investment approach, Review of Financial Studies 28, 650-705.

Inderst, Roman, and Marco Ottaviani, 2012, Financial advice, Journal of Economic Literature 50, 494-512.

Johnson, Woodrow T., 2004, Predictable investment horizons and wealth transfers among mutual fund shareholders, Journal of Finance 59, 1979-2012.

Keswani, Aneel, and David Stolin, 2008, Which money is smart? Mutual fund buys and sells of individual and institutional investors, Journal of Finance 63, 85-118.

Lou, Dong, 2012, A flow-based explanation for return predictability, Review of Financial Studies 25, 3457-3489.

Madrian, Brigitte, and Dennis F. Shea, 2001, The power of suggestion: Inertia in 401(k) participation and savings behavior, Quarterly Journal of Economics 116, 1149-1187.

Mamaysky, Harry, Matthew Spiegel, and Hong Zhang, 2008, Estimating the dynamics of mutual fund alphas and betas, Review of Financial Studies 21, 233-264.

Mullainathan, Sendhil, Markus Nöth, and Antoinette Schoar, 2012, The market for financial advice: An audit study, NBER working paper.

Newey, Whitney K., and Kenneth D. West, 1987, A simple, positive semi-definite, heteroskedasticity and autocorrelation consistent covariance matrix, Econometrica 55, 703708.

Novy-Marx, Robert, 2013, The other side of value: The gross profitability premium, Journal of Financial Economics 108, 1-28.

Palme, Mårten, Annika Sundén, and Paul Söderlind, 2007, How do individual accounts work in the Swedish pension system?, Journal of the European Economic Association 5, 636-646.

Sapp, Travis, and Ashish Tiwari, 2004, Does stock return momentum explain the "smart money" effect?, Journal of Finance 59, 2605-2622.

Seasholes, Mark S., and Ning Zhu, 2010, Individual investors and local bias, Journal of Finance 65, 1987-2011. 
Sialm, Clemens, Laura T. Starks, and Hanjiang Zhang, 2015, Defined contribution pension plans: Sticky or discerning money?, Journal of Finance 70, 805-838.

Sundén, Annika, 2006, The Swedish experience with pension reform, The Oxford Review of Economic Policy 22, 133-148.

Swedish Pensions Agency, 2015, Orange report 2014, Annual report of the Swedish Pension System, Stockholm.

Zheng, Lu, 1999, Is money smart? A study of mutual fund investors' fund selection ability, Journal of Finance 54, 901-933. 
Table I: Funds offered in the Swedish Premium Pension System

\begin{tabular}{|c|c|c|c|c|c|}
\hline & $\begin{array}{r}\text { Total } \\
\text { number of } \\
\text { funds }\end{array}$ & $\begin{array}{r}\text { Average } \\
\text { number of } \\
\text { funds }\end{array}$ & $\begin{array}{r}\text { Average } \\
\text { assets } \\
\text { under } \\
\text { manage- } \\
\text { ment } \\
\text { (millions } \\
\text { SEK) }\end{array}$ & $\begin{array}{r}\text { Average } \\
\text { fees and } \\
\text { expenses } \\
\text { to } \\
\text { investors } \\
(\% \text { per } \\
\text { year })\end{array}$ & $\begin{array}{r}\text { Average } \\
\text { returns (\% } \\
\text { per year) }\end{array}$ \\
\hline All funds & 1,229 & 677 & 173,453 & 1.20 & 2.94 \\
\hline \multicolumn{6}{|l|}{ Equity } \\
\hline - Asia Pacific & 102 & 55 & 2,884 & 1.40 & 2.87 \\
\hline - Emerging markets & 151 & 71 & 13,579 & 1.65 & 15.34 \\
\hline - Europe & 210 & 116 & 9,707 & 1.32 & 2.11 \\
\hline - North America & 73 & 41 & 2,644 & 1.33 & -1.16 \\
\hline - Sweden (and abroad) & 92 & 68 & 35,011 & 0.93 & 5.49 \\
\hline - World & 128 & 61 & 10,409 & 1.32 & -0.56 \\
\hline - Sector & 142 & 76 & 14,040 & 1.43 & -1.85 \\
\hline \multicolumn{6}{|l|}{ Fixed income } \\
\hline - Sweden long (SEK) & 37 & 25 & 3,805 & 0.63 & 4.64 \\
\hline - Sweden short (SEK) & 27 & 21 & 3,164 & 0.57 & 2.63 \\
\hline - Foreign (other currencies) & 127 & 59 & 1,144 & 0.98 & 4.34 \\
\hline \multicolumn{6}{|l|}{ Balanced and target date } \\
\hline - Balanced & 89 & 50 & 6,383 & 1.09 & 2.75 \\
\hline - Target date & 50 & 33 & 20,692 & 0.61 & 0.33 \\
\hline Default & 1 & 1 & 49,990 & 0.47 & 1.75 \\
\hline
\end{tabular}

This table describes the funds offered in the Swedish Premium Pension System during the sample period December 2000 to May 2010. "Total number of funds" counts all funds offered during the sample period in each of thirteen different investment categories. "Average number of funds" and "Average assets under management" are the average of the number of funds on offer, and assets under management (in millions SEK), at the end of each calendar year, in each of the investment categories. Average fees and expenses include fees and expenses charged by the fund management companies and the pension agency to investors minus the fee rebate imposed by the pension agency to participating asset managers. Average returns are the average annualized returns for funds in each investment category. Returns are annualized by multiplying daily returns times 252 . 


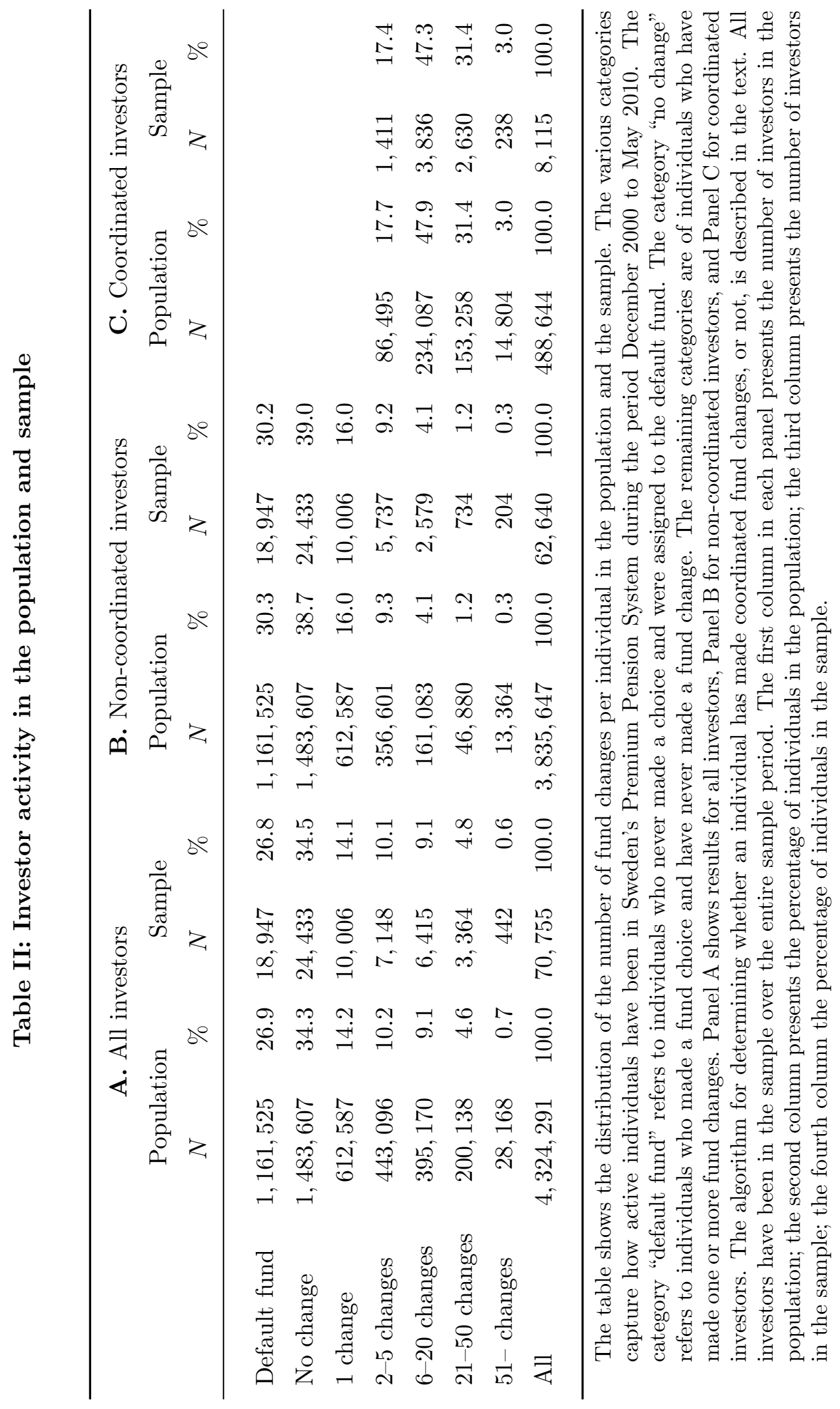




\section{Table III: Investor activity in the sorting and measurement periods}

\begin{tabular}{lrrrr}
\hline & $\begin{array}{r}\text { Average } \\
\text { number of } \\
\text { individuals } \\
\text { per period }\end{array}$ & $\begin{array}{r}\text { Average } \\
\text { percentage of } \\
\text { individuals } \\
\text { per period }\end{array}$ & $\begin{array}{r}\text { Average } \\
\text { number of } \\
\text { changes in } \\
\text { the sorting } \\
\text { period }\end{array}$ & $\begin{array}{r}\text { Average } \\
\text { number of } \\
\text { changes (per } \\
\text { year) in the } \\
\text { measurement } \\
\text { period }\end{array}$ \\
\hline All investors & 62,640 & 100.00 & 0.14 & 0.15 \\
Inactive & 58,589 & 93.53 & 0.00 & 0.05 \\
Active (activity deciles 1 to 9) & 3,654 & 5.83 & 1.39 & 0.85 \\
Highly active (activity decile 10) & 397 & 0.63 & 8.17 & 7.15
\end{tabular}

This table shows the average number of individuals per period in each of three activity categories: Inactive, Active, and Highly Active. It also shows the number of changes these individuals made in the sorting and return measurement periods. The category "Inactive" refers to individuals who did not make any fund changes during the sorting period. The category "Active" refers to individuals who made at least one change but were not in the top decile of activity during the sorting period. The category "Highly active" refers to individuals classified in the top decile of activity during the sorting period. The sorting period is defined as the one-year period finishing ten days before each return measurement day. 


\section{Table IV: Investor activity and performance}

\begin{tabular}{lccc}
\hline & $\begin{array}{c}\text { Mean } \\
\text { (\% per year) }\end{array}$ & $\begin{array}{c}\text { Alpha-FFH } \\
\text { (\% per year) }\end{array}$ & $\begin{array}{c}\text { Alpha-FFCH } \\
\text { (\% per year) }\end{array}$ \\
\hline A. Actual Performance & & & \\
All investors & 4.03 & -0.54 & -0.49 \\
& $(5.40)$ & $(1.10)$ & $(1.12)$ \\
Inactive & 3.82 & -0.76 & -0.70 \\
& $(5.43)$ & $(1.10)$ & $(1.12)$ \\
Active (activity deciles 1 to 9) & 6.86 & 2.32 & 2.09 \\
& $(5.07)$ & $(1.99)$ & $(1.91)$ \\
Highly active (activity decile 10) & $12.57^{* *}$ & $7.89^{* *}$ & $7.56^{* *}$ \\
& $(4.93)$ & $(3.26)$ & $(3.16)$ \\
$t$-test $[p$-value] & {$[0.01]^{* *}$} & {$[<0.01]^{* * *}$} & {$[<0.01]^{* * *}$} \\
& & & \\
B. Counterfactual Performance (excluding fund changes) & & & \\
All investors & 3.71 & -0.90 & -0.83 \\
& {$[0.17]$} & {$[0.10]$} & {$[0.10]$} \\
Inactive & 3.68 & -0.92 & -0.85 \\
& {$[0.30]$} & {$[0.21]$} & {$[0.20]$} \\
Active (activity deciles 1 to 9) & 3.97 & -0.67 & -0.61 \\
Highly active (activity decile 10) & {$[0.09]^{*}$} & {$[0.06]^{*}$} & {$[0.07]^{*}$} \\
& 4.70 & 0.26 & 0.30 \\
& {$[0.01]^{* *}$} & {$[<0.01]^{* * *}$} & {$[0.01]^{* *}$} \\
\hline
\end{tabular}

Panel A of this table shows mean returns and alphas for non-coordinated individuals categorized according to the number of fund changes they made in the sorting period. The category "Inactive" refers to individuals who did not make any fund changes during the sorting period. The category "Active" refers to individuals who made at least one change but were not in the top decile of activity during the sorting period. The category "Highly active" refers to individuals classified in the top decile of activity during the sorting period. The table presents alphas from two different models: a hybrid Fama-French model with global and Swedish market, HML, and SMB factors plus a long minus short bond factor, and a hybrid Fama-French-Carhart model that also incorporates global and Swedish UMD factors. Both factor models are estimated using a Dimson (1979) correction with two leads and two lags. Mean returns and alphas are computed on daily returns and expressed in \% per year. Standard errors, robust to conditional heteroscedasticity and serial correlation up to four lags as in Newey and West (1987), are reported in parentheses. The $t$-test refers to a test of equal means or alphas for the categories "Inactive" and "Highly active." The $p$-values of these tests are reported in square brackets. Panel B presents counterfactual alphas, i.e., the alphas these investors would have obtained if they had not made any fund changes during the entire sample period. The $p$-value of a test of the difference between the actual and a counterfactual alpha is reported in square brackets. ${ }^{*}, * *$, and ${ }^{* * *}$ denote significance at the $10 \%, 5 \%$, and $1 \%$ levels, respectively. 
Table V: The anatomy of active and inactive investors' portfolios

\begin{tabular}{|c|c|c|c|c|}
\hline & All investors & Inactive & $\begin{array}{c}\text { Active } \\
\text { (deciles } \\
1 \text { to } 9 \text { ) }\end{array}$ & $\begin{array}{l}\text { Highly active } \\
\text { (decile 10) }\end{array}$ \\
\hline & \multicolumn{4}{|c|}{ Average portfolio weights on different asset classes and regions } \\
\hline \multicolumn{5}{|c|}{ 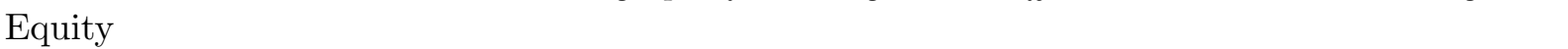 } \\
\hline - Asia Pacific & 1.3 & 1.1 & 3.6 & 5.3 \\
\hline - Emerging markets & 4.9 & 3.1 & 27.3 & 39.8 \\
\hline - Europe & 5.1 & 4.9 & 8.3 & 7.0 \\
\hline - North America & 1.3 & 1.3 & 0.9 & 0.9 \\
\hline - Sweden (and abroad) & 19.7 & 19.7 & 20.9 & 10.2 \\
\hline - World & 5.3 & 5.3 & 5.1 & 3.3 \\
\hline - Sector & 8.8 & 9.0 & 6.2 & 10.7 \\
\hline \multicolumn{5}{|l|}{ Fixed income } \\
\hline - Sweden long (SEK) & 2.1 & 1.7 & 6.6 & 6.6 \\
\hline - Sweden short (SEK) & 1.1 & 0.8 & 4.6 & 10.6 \\
\hline - Foreign (other currencies) & 0.3 & 0.2 & 1.6 & 4.0 \\
\hline \multicolumn{5}{|l|}{ Balanced and target date } \\
\hline - Balanced & 4.4 & 4.5 & 3.3 & 1.1 \\
\hline - Target date & 12.8 & 12.9 & 11.4 & 0.5 \\
\hline \multirow[t]{9}{*}{ Default } & 32.9 & 35.4 & 0.1 & 0.0 \\
\hline & \multicolumn{4}{|c|}{ Average number of funds in portfolio } \\
\hline & 2.51 & 2.45 & 3.30 & 3.45 \\
\hline & \multicolumn{4}{|c|}{ Average fee (including PPS fee) } \\
\hline & 0.63 & 0.62 & 0.81 & 1.01 \\
\hline & \multicolumn{4}{|c|}{ Average invested fund $R^{2}$ with respect to hybrid FF model } \\
\hline & 0.57 & 0.58 & 0.45 & 0.32 \\
\hline & \multicolumn{4}{|c|}{ Average invested fund $R^{2}$ with respect to regional benchmarks } \\
\hline & 0.60 & 0.61 & 0.50 & 0.38 \\
\hline
\end{tabular}

This table characterizes the portfolios of active and inactive individuals in the Swedish Premium Pension System. It presents information about their average portfolio weights (in \%) on thirteen different investment categories (asset classes and geographic regions), the average number of funds in their portfolios, and the average asset management fees they paid (including fees and expenses charged by the fund management companies and the Swedish Pension Agency to investors). The table also includes information about average R-squareds with respect to the Hybrid Fama-French model and a set of asset class/regional benchmarks of the funds these individuals invest in. The category "Inactive" refers to individuals who did not make any fund changes during the sorting period. The category "Active" refers to individuals who made at least one change but were not in the top decile of activity during the sorting period. The category "Highly active" refers to individuals classified in the top decile of activity during the sorting period. Averages in this table are taken across individuals and days. The statistics are computed for the period December 2001 to May 2010. 


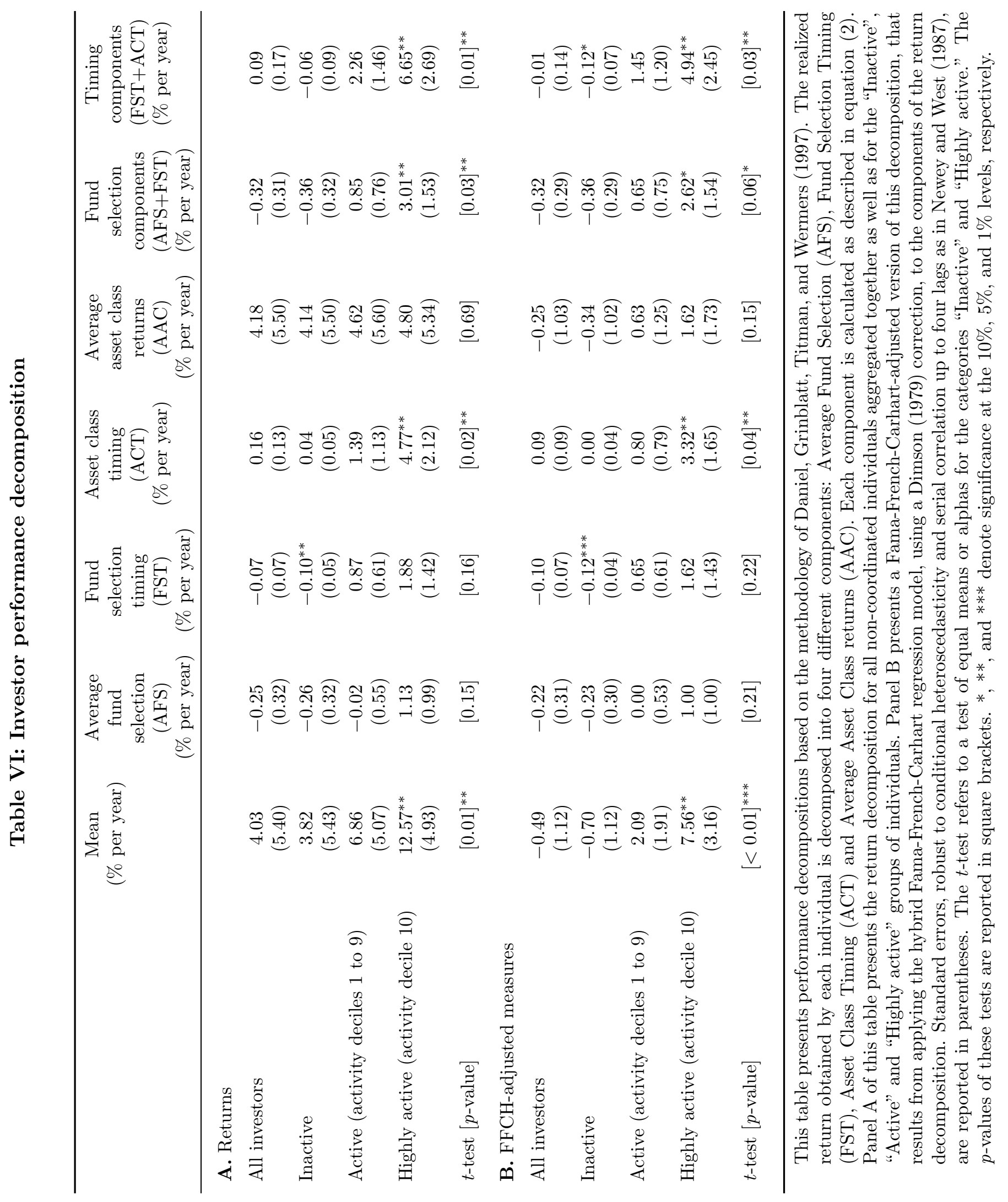




\section{Table VII: The performance of new and old portfolios following portfolio changes}

\begin{tabular}{|c|c|c|c|c|c|c|c|c|c|}
\hline \multirow{2}{*}{ A. Fixed periods } & \multicolumn{3}{|c|}{ Inactive } & \multicolumn{3}{|c|}{ Active } & \multicolumn{3}{|c|}{ Highly active } \\
\hline & $\begin{array}{c}\text { Mean } \\
\text { (\% per } \\
\text { year) }\end{array}$ & $\begin{array}{c}\text { FFH } \\
\text { (\% per } \\
\text { year) }\end{array}$ & $\begin{array}{c}\text { FFCH } \\
(\% \text { per } \\
\text { year })\end{array}$ & $\begin{array}{c}\text { Mean } \\
\text { (\% per } \\
\text { year) }\end{array}$ & $\begin{array}{c}\text { FFH } \\
(\% \text { per } \\
\text { year })\end{array}$ & $\begin{array}{c}\text { FFCH } \\
\text { (\% per } \\
\text { year })\end{array}$ & $\begin{array}{c}\text { Mean } \\
\text { (\% per } \\
\text { year) }\end{array}$ & $\begin{array}{c}\mathrm{FFH} \\
(\% \text { per } \\
\text { year) }\end{array}$ & $\begin{array}{c}\mathrm{FFCH} \\
\text { (\% per } \\
\text { year) }\end{array}$ \\
\hline \multicolumn{10}{|c|}{ One week (day 1-7) } \\
\hline New & 9.71 & 5.15 & 4.95 & 13.24 & 9.01 & 8.84 & 15.54 & 11.44 & 11.35 \\
\hline Old & 4.78 & 0.45 & 0.37 & 7.84 & 3.56 & 3. & 10.87 & 6.67 & 6.59 \\
\hline Difference & 4.9 & $4.70^{* *}$ & $4.58^{* *}$ & $5.41^{* * *}$ & * $5.44^{* * *}$ & $5.38^{* * *}$ & * $\quad 4.67^{* * *}$ & * $\quad 4.77^{* * *}$ & ${ }^{k} \quad 4.75^{* * *}$ \\
\hline$t$-test $[p$-value $]$ & {$[0.02]$} & {$[0.01]$} & {$[0.01]$} & {$[<0.01]$} & {$[<0.01]$} & {$[<0.01]$} & {$[<0.01]$} & {$[<0.01]$} & {$[<0.01]$} \\
\hline \multicolumn{10}{|c|}{ One month (day 1-30) } \\
\hline New & 9.18 & 4.50 & 4.33 & 13.49 & 9.12 & 8.95 & 13.88 & 9.69 & 9.58 \\
\hline Old & 4. & -0.0 & -0 . & & 3. & 3. & 10. & 5 . & 5.8 \\
\hline Difference & & $4.55^{* *}$ & & $5.49^{* *}$ & $5.50^{* * *}$ & $5.44^{* * *}$ & ${ }^{*} \quad 3.74^{* * *}$ & * $\quad 3.79^{* * *}$ & $\quad 3.71^{* * *}$ \\
\hline$t$-test $[p$-value $]$ & {$[0.02]$} & {$[0.01]$} & {$[0.01]$} & {$[0.01]$} & {$[<0.01]$} & {$[<0.01]$} & {$[<0.01]$} & {$[<0.01]$} & {$[<0.01]$} \\
\hline \multicolumn{10}{|c|}{ Six months (day 1-180) } \\
\hline New & 7.24 & & & & 5.66 & & & & 5.51 \\
\hline Old & & -0.32 & -0.40 & & 3.8 & & & 4.3 & 4. \\
\hline Difference & $3.23^{*}$ & $2.77^{*}$ & $2.72^{* *}$ & $1.90^{* *}$ & $1.76^{* *}$ & $1.75^{* *}$ & $1.24^{* *}$ & $1.18^{* *}$ & $1.17^{* *}$ \\
\hline$t$-test $[p$-value $]$ & {$[0.06]$} & {$[0.07]$} & {$[0.05]$} & {$[0.04]$} & {$[0.04]$} & {$[0.04]$} & {$[0.02]$} & {$[0.02]$} & {$[0.02]$} \\
\hline \multicolumn{10}{|c|}{ One month, ignoring the first week (day 8-30) } \\
\hline New & 9.08 & 4.36 & 4.19 & 13.62 & 9.19 & & 13.47 & 9.30 & 9.18 \\
\hline Old & 3.93 & -0.29 & -0.40 & 8.02 & 3.66 & 3.55 & 9.92 & 5.72 & 5.68 \\
\hline Difference & $5.15^{* *}$ & $4.66^{* *}$ & $4.59^{* * *}$ & $5.59^{* * *}$ & * $5.54^{* * *}$ & $5.48^{* * *}$ & * $\quad 3.55^{* * *}$ & * $\quad 3.58^{* * *}$ & $\quad 3.50^{* *}$ \\
\hline$t$-test $[p$-value $]$ & {$[0.01]$} & {$[0.01]$} & {$[<0.01]$} & {$[<0.01]$} & {$[<0.01]$} & {$[<0.01]$} & {$[<0.01]$} & {$[<0.01]$} & {$[<0.01]$} \\
\hline \multicolumn{10}{|c|}{ Six months, iqnoring the first month (day 31-180) } \\
\hline New & 6.80 & 2.00 & 1.89 & 9.14 & 4.78 & 4.67 & 8.66 & 4.59 & 4.56 \\
\hline Old & 4.00 & -0.33 & -0.41 & 8.03 & 3.86 & 3.75 & 7.97 & 3.98 & 3.94 \\
\hline Difference & $2.79^{*}$ & 2.34 & $2.30^{*}$ & 1.11 & 0.92 & 0.92 & 0.68 & 0.60 & 0.62 \\
\hline$t$-test $[p$-value $]$ & {$[0.09]$} & {$[0.12]$} & {$[0.09]$} & {$[0.24]$} & {$[0.32]$} & {$[0.31]$} & {$[0.22]$} & {$[0.28]$} & {$[0.27]$} \\
\hline
\end{tabular}

B. Holding period

Mean

Median
2,606 trading days

1,009 trading days
307 trading days 130 trading days
55 trading days 29 trading days

Panel A of this shows the average returns and alphas of non-coordinated investors' "new" and "old" portfolios following a portfolio change. Investors are categorized according to the number of fund changes they made in the one-year period finishing ten days before the portfolio change date. The category "Inactive" refers to individuals who did not make any fund changes during the sorting period. The category "Active" refers to individuals who made at least one change but were not in the top decile of activity during the sorting period. The category "Highly active" refers to individuals classified in the top decile of activity during the sorting period. The "new" and "old" portfolios are followed for either one week, one month, six months, one month ignoring the first week or six months ignoring the first month, after the portfolio change. Mean returns and alphas (see text for details) are computed on daily returns and expressed in \% per year. Alpha measures are estimated using a Dimson (1979) correction with two leads and two lags. The $p$-values of a $t$-test of zero difference, based on standard errors robust to conditional heteroscedasticity and serial correlation up to four lags as in Newey and West (1987), are reported in square brackets. Panel B reports estimated holding periods for each of these three investors groups based on a parametric Weibull duration model. *, **, and *** denote significance at the $10 \%$, $5 \%$, and $1 \%$ levels, respectively. 


\section{Table VIII: Performance chasing}

\begin{tabular}{|c|c|c|c|c|}
\hline & $\begin{array}{l}\text { Previous } \\
\text { month }\end{array}$ & $\begin{array}{l}\text { Previous } \\
\text { three months }\end{array}$ & $\begin{array}{l}\text { Previous } \\
\text { six months }\end{array}$ & $\begin{array}{l}\text { Previous } \\
\text { twelve months }\end{array}$ \\
\hline \multicolumn{5}{|c|}{ A. $\%$ invested in top decile funds: portfolio change dates } \\
\hline All investors & 34.0 & 39.4 & 40.7 & 40.3 \\
\hline $\begin{array}{l}\text { Inactive } \\
\text { Active (activity deciles } 1 \text { to } 9 \text { ) } \\
\text { Highly active (activity decile } 10 \text { ) }\end{array}$ & $\begin{array}{l}20.7 \\
35.2 \\
45.0\end{array}$ & $\begin{array}{l}24.9 \\
41.1 \\
51.0\end{array}$ & $\begin{array}{l}26.5 \\
42.9 \\
51.4\end{array}$ & $\begin{array}{l}28.2 \\
42.7 \\
48.8\end{array}$ \\
\hline \multicolumn{5}{|c|}{ B. \% invested in top decile funds: portfolio all dates } \\
\hline All investors & 5.2 & 5.4 & 5.8 & 5.9 \\
\hline $\begin{array}{l}\text { Inactive } \\
\text { Active (activity deciles } 1 \text { to } 9 \text { ) } \\
\text { Highly active (activity decile } 10 \text { ) }\end{array}$ & $\begin{array}{r}4.3 \\
15.9 \\
31.1\end{array}$ & $\begin{array}{r}4.3 \\
19.0 \\
42.3\end{array}$ & $\begin{array}{r}4.3 \\
23.1 \\
47.7\end{array}$ & $\begin{array}{r}4.2 \\
27.8 \\
49.0\end{array}$ \\
\hline \multicolumn{5}{|c|}{$\begin{array}{l}\text { Panel A of this table shows the average percentage of an individual portfolio invested in funds ranked } \\
\text { in the top decile of past performance on the day of the portfolio change (new portfolio). Panel B shows } \\
\text { the average percentage of an individual portfolio invested in funds ranked in the top decile of past } \\
\text { performance across the sample (all days). We base daily past performance deciles on fund returns during } \\
\text { the one-, three-, six-, or twelve-month period ending three days before each decile formation date. These } \\
\text { figures are presented for all investors in the sample as well as for "inactive", "active" and "highly active" } \\
\text { investors. The category "Inactive" refers to individuals who did not make any fund changes during the } \\
\text { sorting period. The category "Active" refers to individuals who made at least one change but were not } \\
\text { in the top decile of activity during the sorting period. The category "Highly active" refers to individuals } \\
\text { classified in the top decile of activity during the sorting period. }\end{array}$} \\
\hline
\end{tabular}




\section{Table IX: Prior performance-based return decomposition}

\begin{tabular}{|c|c|c|c|}
\hline & $\begin{array}{l}\text { Mean } \\
(\% \text { per year })\end{array}$ & $\begin{array}{c}\text { Excess over } \\
\text { performance } \\
\text { chasing } \\
\text { strategy } \\
\text { (\% per year) }\end{array}$ & $\begin{array}{c}\text { Average } \\
\text { performance } \\
\text { chasing } \\
\text { returns } \\
\text { (\% per year) }\end{array}$ \\
\hline \multicolumn{4}{|l|}{ A. Returns } \\
\hline All investors & $\begin{array}{c}4.03 \\
(5.40)\end{array}$ & $\begin{array}{c}0.31 \\
(1.40)\end{array}$ & $\begin{array}{c}3.71 \\
(4.98)\end{array}$ \\
\hline Inactive & $\begin{array}{c}3.82 \\
(5.43)\end{array}$ & $\begin{array}{c}0.20 \\
(1.44)\end{array}$ & $\begin{array}{c}3.61 \\
(5.01)\end{array}$ \\
\hline Active (activity deciles 1 to 9 ) & $\begin{array}{c}6.86 \\
(5.07)\end{array}$ & $\begin{array}{c}2.06 \\
(1.53)\end{array}$ & $\begin{array}{c}4.80 \\
(4.65)\end{array}$ \\
\hline Highly active (activity decile 10) & $\begin{array}{l}12.57^{* *} \\
(4.93)\end{array}$ & $\begin{array}{l}4.99^{* * *} \\
(1.93)\end{array}$ & $\begin{array}{r}7.58^{*} \\
(4.43)\end{array}$ \\
\hline$t$-test $[p$-value $]$ & {$[0.01]^{* *}$} & {$[0.04]^{* *}$} & {$[0.07]^{*}$} \\
\hline \multicolumn{4}{|l|}{ B. FFCH-adjusted measures } \\
\hline All investors & $\begin{array}{c}-0.49 \\
(1.12)\end{array}$ & $\begin{array}{c}0.18 \\
(1.04)\end{array}$ & $\begin{array}{c}-0.66 \\
(1.26)\end{array}$ \\
\hline Inactive & $\begin{array}{c}-0.70 \\
(1.12)\end{array}$ & $\begin{array}{c}0.05 \\
(1.08)\end{array}$ & $\begin{array}{c}-0.75 \\
(1.27)\end{array}$ \\
\hline Active (activity deciles 1 to 9 ) & $\begin{array}{c}2.09 \\
(1.91)\end{array}$ & $\begin{array}{c}1.74 \\
(1.33)\end{array}$ & $\begin{array}{c}0.35 \\
(1.30)\end{array}$ \\
\hline Highly active (activity decile 10) & $\begin{array}{l}7.56^{* *} \\
(3.16)\end{array}$ & $\begin{array}{l}5.11^{* * *} \\
(1.92)\end{array}$ & $\begin{array}{c}2.45 \\
(2.06)\end{array}$ \\
\hline$t$-test $[p$-value $]$ & {$[<0.01]^{* * *}$} & {$[0.03]^{* *}$} & {$[0.08]^{*}$} \\
\hline
\end{tabular}

In this table the realized returns obtained by each individual are decomposed into two components: the returns she would have obtained if she had invested in funds classified in the same past performance deciles she invested in one year before (Average performance chasing returns) and the returns obtained on top of (or below) that strategy (Excess over performance chasing strategy). Panel A of this table presents the decomposition for all non-coordinated individuals aggregated together as well as for the "Inactive", "Active" and "Highly active" groups of individuals. Panel B presents a Fama-French-Carhart-adjusted version of this decomposition, that results from applying the hybrid Fama-French-Carhart regression model, using a Dimson (1979) correction, to the components of the return decomposition. Standard errors, robust to conditional heteroscedasticity and serial correlation up to four lags as in Newey and West (1987), are reported in parentheses. The $t$-test refers to a test of equal means or alphas for the categories "Inactive" and "Highly active." The $p$-values of these tests are reported in square brackets. $*, * *$, and $* * *$ denote significance at the $10 \%, 5 \%$, and $1 \%$ levels, respectively. 
Table X: Investor characteristics, activity, and performance

\begin{tabular}{|c|c|c|c|c|}
\hline \multirow[t]{2}{*}{ A. Return regressions } & \multicolumn{2}{|c|}{$\mathrm{FFH}$} & \multicolumn{2}{|c|}{$\mathrm{FFCH}$} \\
\hline & I & II & III & IV \\
\hline Constant (inactive) & $\begin{array}{c}-0.761 \\
(1.095)\end{array}$ & $\begin{array}{r}-1.096 \\
(1.589)\end{array}$ & $\begin{array}{c}-0.696 \\
(1.108)\end{array}$ & $\begin{array}{c}-1.214 \\
(1.589)\end{array}$ \\
\hline Active (activity deciles 1 to 9 ) & $\begin{array}{c}3.084^{*} \\
(1.744)\end{array}$ & $\begin{array}{c}3.098^{*} \\
(1.728)\end{array}$ & $\begin{array}{c}2.781^{*} \\
(1.629)\end{array}$ & $\begin{array}{r}2.813^{*} \\
(1.613)\end{array}$ \\
\hline Highly active (activity decile 10) & $\begin{array}{l}8.655^{* * *} \\
(3.168)\end{array}$ & $\begin{array}{l}8.691^{\text {*** }} \\
(3.169)\end{array}$ & $\begin{array}{l}8.262^{* * *} \\
(3.052)\end{array}$ & $\begin{array}{l}8.298^{* * *} \\
(3.053)\end{array}$ \\
\hline Age & & $\begin{array}{c}0.002 \\
(0.017)\end{array}$ & & $\begin{array}{c}0.005 \\
(0.017)\end{array}$ \\
\hline Male & & $\begin{array}{c}0.619^{* *} \\
(0.279)\end{array}$ & & $\begin{array}{c}0.676^{* *} \\
(0.276)\end{array}$ \\
\hline Pension rights (in thousands) & & $\begin{array}{c}-0.026 \\
(0.078)\end{array}$ & & $\begin{array}{c}-0.030 \\
(0.078)\end{array}$ \\
\hline$R$-squared & 0.666 & 0.667 & 0.668 & 0.669 \\
\hline B. Groups composition & All investors & Inactive & $\begin{array}{c}\text { Active } \\
\text { (deciles } \\
1 \text { to } 9 \text { ) }\end{array}$ & $\begin{array}{l}\text { Highly active } \\
\quad(\text { decile } 10)\end{array}$ \\
\hline Age & 52.2 & 52.3 & 51.5 & 51.7 \\
\hline Male & $52 \%$ & $52 \%$ & $54 \%$ & $61 \%$ \\
\hline Pension rights & 4,023 & 3,981 & 4,567 & 4,687 \\
\hline
\end{tabular}

Panel A of this table presents the results of pooled regressions of non-coordinated individuals' daily excess returns on factors, measures of the number of fund changes by each investor and other individual characteristics. The factors are those included in the Fama-French and Fama-French-Carhart Hybrid factor models (see the text for details). The coefficients on these factors are allowed to vary across the individuals' characteristics. For brevity, the coefficients on the factors are not presented in the table. The number of fund changes prior to the performance evaluation period is measured using a dummy variable for each activity category (see Table IV). Other characteristics are the individuals' age in year 2000 , gender (one if male, and otherwise zero) and pension rights in year 2000, which is a proxy for income. The constant and coefficients on the dummy variables are expressed in \% per year. Standard errors, robust to conditional heteroscedasticity and spatial autocorrelations with four lags as in Driscoll and Kraay (1998), are reported in parentheses. Panel B shows the average age and pension rights in year 2000 and the proportion of males in the inactive, active and highly active investor groups. The sample consists of 62,640 individuals followed daily over the period December 2000 to May 2010. *, **, and *** denote significance at the $10 \%, 5 \%$, and $1 \%$ levels, respectively. 


\section{Table XI: Coordinated investors' performance}

\begin{tabular}{lccc}
\hline & $\begin{array}{c}\text { Mean } \\
\text { ( per year) }\end{array}$ & $\begin{array}{c}\text { Alpha-FFH } \\
\text { (\% per year) }\end{array}$ & $\begin{array}{c}\text { Alpha-FFCH } \\
\text { (\% per year) }\end{array}$ \\
\hline A. Performance of coordinated investors & & & \\
Full sample (gross) & 3.78 & -0.62 & -0.50 \\
& $(5.10)$ & $(1.28)$ & $(1.22)$ \\
Coordinated period (gross) & 5.21 & 0.61 & 0.86 \\
& $(4.90)$ & $(1.70)$ & $(1.60)$ \\
Full sample (net of 1.5\% fee) & 2.28 & $-2.12^{*}$ & -2.00 \\
& $(5.10)$ & $(1.28)$ & $(1.22)$ \\
Coordinated period (net of 1.5\% fee) & 3.71 & -0.89 & -0.64 \\
& $(4.90)$ & $(1.70)$ & $(1.60)$ \\
B. Difference to "non-coordinated, inactive" & & & \\
Full sample (gross) & & & 0.20 \\
& -0.03 & 0.14 & {$[0.78]$} \\
Coordinated period (gross) & {$[0.97]$} & {$[0.87]$} & {$[0.30]$} \\
& 1.39 & 1.37 & -1.30 \\
Full sample (net of 1.5\% fee) & {$[0.46]$} & {$[0.39]$} & {$[0.07]^{*}$} \\
Coordinated period (net of 1.5\% fee) & -1.53 & -1.36 & 0.05 \\
& {$[0.12]$} & {$[0.10]$} & {$[0.97]$}
\end{tabular}

The table presents the performance of coordinated individuals during the entire sample period and during the coordinated period. Performance is alternatively reported gross or net of a financial advisor fee of $1.5 \%$ per year. The first column presents the mean returns obtained by individuals in each category. The remaining columns present alphas from two different models: a hybrid Fama-French model with global and Swedish market, HML, and SMB factors plus a long minus short bond factor, and a hybrid Fama-French-Carhart model that also incorporates global and Swedish UMD factors. Both factor models are estimated using a Dimson (1979) correction with two leads and two lags. The statistics are computed on daily returns of individuals' portfolios during the period December 2000 to May 2010. Mean returns and alphas are expressed in \% per year. Standard errors, robust to conditional heteroscedasticity and serial correlation up to four lags as in Newey and West (1987), are reported in parentheses. The table also reports the difference between coordinated investors' means or alphas and those of inactive noncoordinated investors. The p-values of these tests are reported in square brackets. ${ }^{*},{ }^{* *}$, and ${ }^{* *}$ denote significance at the $10 \%, 5 \%$, and $1 \%$ levels, respectively. 
Table XII: The impact of flows on fund performance

\begin{tabular}{|c|c|c|c|c|}
\hline & $\begin{array}{l}\quad \text { I } \\
\text { Dummy for } \\
\text { relative } \\
\text { flow }>5\end{array}$ & \begin{tabular}{l}
\multicolumn{1}{c}{ II } \\
Dummy for \\
relative \\
flow $>10$
\end{tabular} & $\begin{array}{l}\quad \text { III } \\
\text { Dummy for } \\
\text { relative } \\
\text { flow }>20\end{array}$ & \begin{tabular}{l}
\multicolumn{1}{c}{ IV } \\
Dummy for \\
relative \\
flow $>30$
\end{tabular} \\
\hline \multicolumn{5}{|c|}{ A. Contemporaneous response } \\
\hline Relative outflow & $\begin{array}{c}-0.050^{* *} \\
(0.020)\end{array}$ & $\begin{array}{c}-0.060^{* *} \\
(0.029)\end{array}$ & $\begin{array}{c}-0.078^{* *} \\
(0.038)\end{array}$ & $\begin{array}{c}-0.095^{* *} \\
(0.044)\end{array}$ \\
\hline Relative inflow & $\begin{array}{c}0.025 \\
(0.016)\end{array}$ & $\begin{array}{c}0.021 \\
(0.022)\end{array}$ & $\begin{array}{c}0.001 \\
(0.037)\end{array}$ & $\begin{array}{c}0.006 \\
(0.050)\end{array}$ \\
\hline \multicolumn{5}{|c|}{ B. Cumulative response: } \\
\hline Relative outflow & $\begin{array}{l}-0.072^{* * *} \\
(0.013)\end{array}$ & $\begin{array}{l}-0.097^{* * *} \\
(0.016)\end{array}$ & $\begin{array}{l}-0.107^{* * *} \\
(0.024)\end{array}$ & $\begin{array}{c}-0.074^{* *} \\
(0.034)\end{array}$ \\
\hline Relative inflow & $\begin{array}{c}-0.004 \\
(0.014)\end{array}$ & $\begin{array}{c}0.003 \\
(0.018)\end{array}$ & $\begin{array}{c}0.012 \\
(0.030)\end{array}$ & $\begin{array}{c}0.032 \\
(0.042)\end{array}$ \\
\hline \multicolumn{5}{|l|}{ After 20 days } \\
\hline Relative outflow & $\begin{array}{l}-0.068^{* * *} \\
(0.012)\end{array}$ & $\begin{array}{l}-0.090^{* * *} \\
(0.015)\end{array}$ & $\begin{array}{l}-0.100^{* * *} \\
(0.023)\end{array}$ & $\begin{array}{c}-0.071^{* *} \\
(0.032)\end{array}$ \\
\hline Relative inflow & $\begin{array}{r}-0.003 \\
(0.013)\end{array}$ & $\begin{array}{r}-0.002 \\
(0.017)\end{array}$ & $\begin{array}{c}0.006 \\
(0.028)\end{array}$ & $\begin{array}{c}0.022 \\
(0.039)\end{array}$ \\
\hline \multicolumn{5}{|c|}{ C. Percentage of large flow days } \\
\hline $\begin{array}{l}\text { Outflow dummy } \\
\text { Inflow dummy }\end{array}$ & $\begin{array}{l}3.32 \\
3.89\end{array}$ & $\begin{array}{l}1.24 \\
1.82\end{array}$ & $\begin{array}{l}0.47 \\
0.75\end{array}$ & $\begin{array}{l}0.28 \\
0.44\end{array}$ \\
\hline \multicolumn{5}{|c|}{ Percentage of flows (on dummy days) due to coordinated investors } \\
\hline $\begin{array}{l}\text { Outflow } \\
\text { Inflow }\end{array}$ & $\begin{array}{l}78 \\
69\end{array}$ & $\begin{array}{l}85 \\
77\end{array}$ & $\begin{array}{l}90 \\
85\end{array}$ & $\begin{array}{l}93 \\
88\end{array}$ \\
\hline
\end{tabular}

Panel A of this table presents the results of panel regressions of a mutual fund's daily abnormal return on measures of relative flows. The daily abnormal return for each fund is obtained from the FFH model as discussed in the text. The relative outflow (inflow) is the fund specific outflow (inflow) on a day divided by the time series average outflow (inflow) of the fund. Specifications I-IV use dummies that capture whether relative outflows (inflows) are larger than certain thresholds on a given day. The regressions include ten lags of the abnormal return variable and fund fixed effects. Standard errors, robust to conditional heteroscedasticity and spatial autocorrelations up to four lags as in Driscoll and Kraay (1998) are reported in parentheses. Panel B presents cumulative return responses to outflows and inflows from a non-linear VAR system with two equations: an equation in which abnormal returns depend on ten lags of itself and the contemporaneous and lagged (ten lags) outflow and inflow dummy variables; and a second equation in which relative flows (positive flows minus negative flows) depend on ten lags of itself and ten lags of abnormal returns. The VAR models include fund fixed effects. Bootstrapped standard errors are reported in parentheses. Panel $\mathrm{C}$ shows the fraction of observations in which the dummy variables equal one and the fraction of flows due to coordinated investors in those days (average ratio of coordinated investors' flows over total flows). ${ }^{*}, * *$, and ${ }^{* * *}$ denote significance at the $10 \%, 5 \%$, and $1 \%$ levels, respectively. 